\title{
Carbon accumulation rates of Holocene peatlands in central-eastern Europe document the driving role of human impact over the past $\mathbf{4 0 0 0}$ years
}

\author{
Jack Longman $^{1}$, Daniel Veres ${ }^{2}$, Aritina Haliuc ${ }^{2,3}$, Walter Finsinger ${ }^{4}$, Vasile Ersek ${ }^{5}$, Daniela Pascal ${ }^{6,7}$, Tiberiu Sava ${ }^{6}$, \\ and Robert Begy ${ }^{8}$ \\ ${ }^{1}$ Marine Isotope Geochemistry, Institute for Chemistry and Biology of the Marine Environment (ICBM), \\ University of Oldenburg, 26129 Oldenburg, Germany \\ ${ }^{2}$ Romanian Academy, Institute of Speleology, 400006 Cluj-Napoca, Romania \\ ${ }^{3}$ EPOC, UMR 5805, Université de Bordeaux, 33600 Pessac, France \\ ${ }^{4}$ ISEM, University of Montpellier, CNRS, EPHE, IRD, 34095 Montpellier, France \\ ${ }^{5}$ Department of Geography and Environmental Sciences, Northumbria University, Newcastle-upon-Tyne NE1 8ST, UK \\ ${ }^{6}$ RoAMS Laboratory, Horia Hulubei National Institute for Physics and Nuclear Engineering, \\ 077125 Bucharest-Măgurele, Romania \\ ${ }^{7}$ Faculty of Geography, University of Bucharest, 030018 Bucharest, Romania \\ ${ }^{8}$ Interdisciplinary Research Institute on Bio-Nano-Sciences, Babes-Bolyai University, 400271 Cluj-Napoca, Romania
}

Correspondence: Jack Longman (jack.longman@uni-oldenburg.de)

Received: 7 June 2021 - Discussion started: 9 June 2021

Accepted: 2 November 2021 - Published: 21 December 2021

\begin{abstract}
Peatlands are one of the largest terrestrial carbon sinks on the planet, yet little is known about the carbon accumulation rates (CARs) of mountainous peatlands. The long-term variability in the size of the associated carbon sink and its drivers remain largely unconstrained, especially when the long-term anthropogenic impact is also considered. Here, we present a composite CAR record of nine peatlands from central-eastern Europe (Romania and Serbia) detailing variability in the rates of carbon accumulation during the Holocene. We show examples of extremely high long-term rates of carbon accumulation (LORCA $>120 \mathrm{~g} \mathrm{C} \mathrm{m}^{-2} \mathrm{yr}^{-1}$ ), indicating that mountain peatlands constitute an efficient regional carbon sink at times. By comparing our data to modelled palaeoclimatic indices and to measures of anthropogenic impact we disentangle the drivers of peat carbon accumulation in the area. Variability in early- and midHolocene CARs is linked to hydroclimatic controls, with high CARs occurring during the early Holocene and lower CARs associated with the transition to cooler and moister mid-Holocene conditions. By contrast, after 4000 years (calibrated) before present (years BP), the trends in CARs indi-
\end{abstract}

cate a divergence from hydroclimate proxies, suggesting that other processes became the dominant drivers of peat CARs. We propose that enhanced erosion following tree cover reduction as well as increased rates of long-distance atmospheric dust fallout might have played a role, as both processes would result in enhanced mineral and nutrient supply to bog surfaces, stimulating peatland productivity. Surprisingly though, for the last 1000 years, reconstructed temperature is significantly correlated with CARs, with rising temperatures linked to higher CARs. Under future climate conditions, which are predicted to be warmer in the region, we predict that peat growth may expand but that this is entirely dependent upon the scale of human impact directly affecting the sensitive hydrological budget of these peatlands.

\section{Introduction}

Peatlands are some of the most proficient mediums for longterm carbon (C) sequestration in the terrestrial environment (Loisel et al., 2014), with the $\mathrm{C}$ sink in globally distributed peatlands estimated to be as high as ca. $600 \mathrm{GtC}$ (gigatonnes 
of carbon) (Dargie et al., 2017; Yu et al., 2010). This carbon sink has developed primarily during the Holocene; however, the rates of development vary both temporally and spatially, driven by shifts in nutrient availability (Kylander et al., 2018; Ratcliffe et al., 2020), moisture and temperature (Charman et al., 2013; Loisel et al., 2014; Yu et al., 2010), and the speed at which accumulated peat decomposes (Clymo et al., 1998). Specifically, warmer and wetter climates tend to lead to higher peat carbon accumulation rates (CARs) (Loisel et al., 2014), as warmer temperatures stimulate peat growth more than organic matter decomposition (Charman et al., 2013, 2015; Yu et al., 2010).

As such, understanding the history of carbon accumulation in peatlands is important for critically assessing the terrestrial carbon cycle in our anthropogenically altered world (Hugelius et al., 2020; Loisel et al., 2021). Model-derived estimates of future climatic change suggest that peatlands will act as an efficient carbon sink as climate warms (GallegoSala et al., 2018), as observed in reconstructions of warm periods in Earth's past (Treat et al., 2019). However, this conclusion is far from certain, as land-use-driven degradation of peat since the 1960s has led to peatlands acting as a net source of carbon (Leifeld et al., 2019). Land use and peatland degradation also played a major role in anthropogenic carbon release long before the 1960s, with evidence that humans have progressively altered the terrestrial carbon cycle for the last 7000 years (Kaplan et al., 2011; Ruddiman et al., 2011). Greater land exploitation leads to enhanced carbon release, so this trend will likely continue as human pressure on land use is expected to increase (Kaplan et al., 2011; Ruddiman and Ellis, 2009).

For individual peatlands, fire and grazing disturbances negatively impact peatland development (Nieveen et al., 2005; Worrall and Clay, 2012) due to the loss of surface peat or changes to local vegetation (Garnett et al., 2000; Kuhry, 1994). Furthermore, draining of wetlands and the extraction of peat plays a major role in both long-term carbon accumulation in peat and its short-term release back into the atmosphere (Holden et al., 2011; Turetsky et al., 2011), with hydrological shifts potentially altering the ecology of bogs (Tahvanainen, 2011). Furthermore, climate change also influences the stability of the extensive Northern Hemisphere boreal peatlands, potentially resulting in the enhanced release of methane, thereby further exacerbating the effects of rising global temperatures (Schaefer et al., 2014; Schuur et al., 2015). Finally, it is possible that increased erosion as a result of forest removal either by human actions or natural causes may lead to increased mineral in-wash (Longman et al., 2017a), with dust deposition potentially stimulating peat growth (Kylander et al., 2018). Due to the complex relations between these factors and the equally complex response of peat environments, the interaction of anthropogenic disturbances and peat growth over long timescales as well as the impact of anthropogenic disturbances on peat CARs are currently unclear.
Mountain bogs are rarely considered in estimates of carbon storage (Chen et al., 2014), likely due to their limited extent when compared with tropical and boreal marshes and peatlands (Dargie et al., 2017; Loisel et al., 2014). This lack of studies extends to the Carpathian Mountains, the second largest European mountain range, which stretches for nearly $1500 \mathrm{~km}$ from the Czech Republic to Serbia (Fig. 1). In the Carpathians, only one high-resolution study of CARs has been completed at Tăul Muced, Romania, indicating that about $250 \mathrm{tC}$ (tonnes of carbon) may have been sequestered over the past 7000 years (Panait et al., 2017). This is insignificant in isolation, but when all mountain peatlands from this mountain range (Pop, 1960), including substantially larger bogs such as Mohos in eastern Romania, which is roughly 40 times larger (Longman et al., 2017b), are considered, it may be that Carpathian bogs constitute an important carbon sink for the overall carbon budget - one which may represent a regionally important carbon stock.

Here, we present CARs for nine bogs in central-eastern Europe, reconstructing the variability in carbon accumulation for the past 10000 years. By combining these reconstructions with change-point modelling and proxies of past hydroclimatic variability, we assess the drivers of carbon accumulation in mountain regions. We provide a first estimate of carbon storage in these environments and also investigate the extent to which human activity in mountain regions may have impacted peatland accumulation rates throughout the Holocene.

\section{Methods and materials}

\subsection{Site locations and coring}

We analysed the organic matter content of eight bogs in Romania $(n=6)$ and Serbia $(n=2)$ (see Fig. 1 and Table 1$)$ and combined this information with previously published CAR data from the Tăul Muced (TM) bog (Panait et al., 2017). All of the new sites in this study were cored using a Russian corer, with samples immediately wrapped in cling film and shipped to laboratories for description and analysis.

\subsection{Age modelling}

For all bogs, radiocarbon accelerator mass spectrometry (AMS ${ }^{14} \mathrm{C}$ ) dating analyses were completed to estimate the age of peat accumulation. The majority of samples were taken from $1 \mathrm{~cm}$ slices of bulk sediment/peat, which is an approach that has been shown to yield reliable age information (Holmquist et al., 2016). The samples from the Despotovac (DES), Mluha (MLH), and Iezerul Mare (IZM) sites were pretreated and measured at RoAMS laboratory at the Horia Hulubei National Institute of Physics and Nuclear Engineering (IFIN-HH) according to the protocols described in Sava et al. (2019). Samples from the Sureanu (SUR), Zănoaga Roşie (ZNG), MLH, and Mohos (MOH) bogs were mea- 


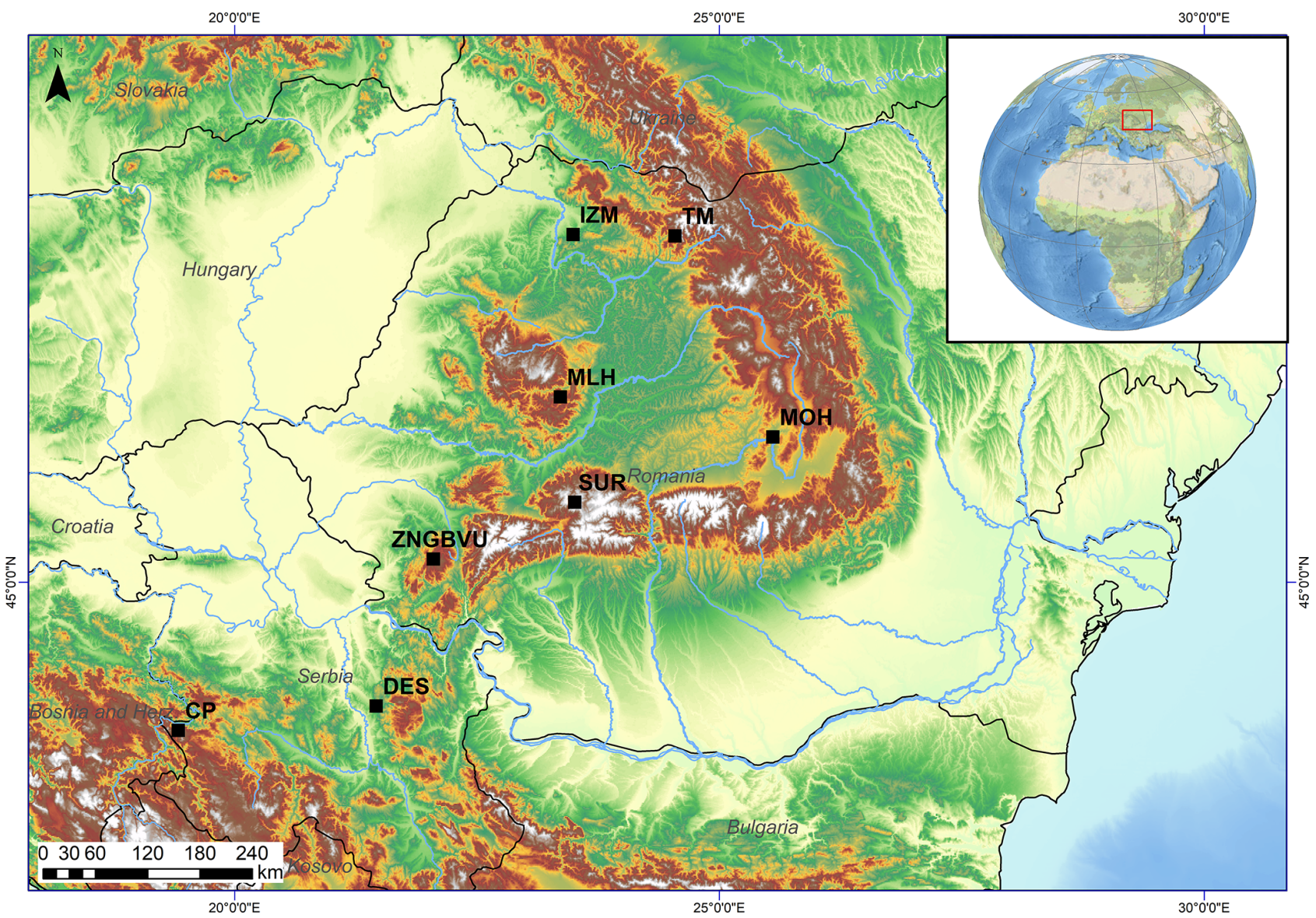

Figure 1. Map of central-eastern Europe, indicating where all of the sites used in this study are located. Study sites are marked using solid squares, and the site codes indicate the site name: Iezerul Mare (IZM), Tăul Muced (TM), Mohos (MOH), Mluha (MLH), Sureanu (SUR), Zănoaga Roşie (ZNG), Baia Vulturilor (BVU), Despotovac (DES), and Crveni Potok (CP).

Table 1. The main results of this study. Listed here are the details of each bog involved in this work, including their location, type (O ombrotrophic, B - blanket, or F - fen), size, depth, and age. In addition, where known, a coring date is indicated. Also presented are the average carbon content, bulk density, and peat growth.

\begin{tabular}{|c|c|c|c|c|c|c|c|c|c|c|c|c|}
\hline Peat bog & Code & $\begin{array}{r}\text { Latitude } \\
\left({ }^{\circ} \mathrm{N}\right)\end{array}$ & $\begin{array}{r}\text { Longitude } \\
\left({ }^{\circ} \mathrm{E}\right)\end{array}$ & Altitude & $\begin{array}{l}\text { Bog } \\
\text { type }\end{array}$ & $\begin{array}{r}\text { Mire } \\
\text { area } \\
\left(\mathrm{km}^{2}\right)\end{array}$ & $\begin{array}{r}\text { Coring } \\
\text { date }\end{array}$ & $\begin{array}{r}\text { Median } \\
\mathrm{C} \\
\text { content } \\
(\%)\end{array}$ & $\begin{array}{r}\text { Median } \\
\text { density } \\
\left(\mathrm{g} \mathrm{cm}^{-3}\right)\end{array}$ & $\begin{array}{r}\text { Basal } \\
\text { age } \\
\text { (years BP) }\end{array}$ & $\begin{array}{r}\text { Basal } \\
\text { depth } \\
(\mathrm{cm})\end{array}$ & $\begin{array}{r}\text { Peat } \\
\text { growth } \\
\left(\mathrm{cm} \mathrm{yr}^{-1}\right)\end{array}$ \\
\hline Crveni Potok & $\mathrm{CP}$ & 19.42 & 43.91 & 1090 & $\mathrm{O}$ & 0.19 & October 2012 & 44.93 & 0.14 & 9560 & 270 & 0.028 \\
\hline Despotovac & DES & 21.46 & 44.09 & 100 & $\mathrm{~F}$ & 0.001 & August 2015 & 17.47 & 0.35 & 1779 & 200 & 0.112 \\
\hline Zănoaga Roşie & ZNG & 22.05 & 45.17 & 1400 & B & 1 & 2015 & 49.58 & 0.18 & 11936 & 200 & 0.016 \\
\hline Baia Vulturilor & BVU & 22.05 & 45.17 & 1400 & B & 1 & 2015 & 45.83 & 0.11 & 4030 & 193 & 0.047 \\
\hline Sureanu & SUR & 23.51 & 45.58 & 1840 & $\mathrm{O}$ & 0.009 & October 2014 & 42.16 & 0.095 & 7390 & 594 & 0.080 \\
\hline Mluha & MLH & 23.36 & 46.34 & 1240 & $\mathrm{O}$ & 0.1 & 2014 & 49.04 & 0.204 & 7863 & 620 & 0.078 \\
\hline Mohos & $\mathrm{MOH}$ & 25.55 & 46.05 & 1050 & $\mathrm{O}$ & 0.8 & 2014 & 45.69 & 0.071 & 10849 & 940 & 0.086 \\
\hline Tăul Muced & TM & 24.54 & 47.47 & 1360 & $\mathrm{O}$ & 0.02 & Unknown & 48.95 & 0.074 & 7769 & 450 & 0.057 \\
\hline Iezerul Mare & IZM & 23.49 & 47.48 & 1005 & $\mathrm{O}$ & 0.1 & 2021 & 45.53 & 0.18 & 6177 & 750 & 0.121 \\
\hline
\end{tabular}

sured at the HEKAL AMS Laboratory, MTA ATOMKI Institute for Nuclear Research of the Hungarian Academy of Sciences in Debrecen. Five dates from SUR were analysed by the ${ }^{14}$ Chrono Centre at Queen's University Belfast (Longman et al., 2017a). Samples from Crveni Potok (CP) were analysed on extracted plant macrofossils at the Poznan Radiocarbon Laboratory (Finsinger et al., 2017). Samples from Baia Vulturilor (BVU) were measured at the Center for Physical Sciences and Technology Vilnius, Lithuania. A summary of the radiocarbon dates and laboratory procedures for each 
bog investigated in this study can be found in Table S1 in the Supplement. Age-depth modelling was completed using Bacon (Blaauw and Christen, 2011), with ages calibrated using IntCal20 (Reimer et al., 2020), and the models are presented in Figs. S1-S8 in the Supplement. For TM, we used the published age model of Panait et al. (2017).

\subsection{Carbon accumulation rate (CAR) calculations}

For each bog, samples of exactly $1 \mathrm{~cm}^{3}$ were taken and dried before being weighed to estimate dry bulk density. Organic content was then measured via loss on ignition, which was performed in a muffle furnace at $550^{\circ} \mathrm{C}$, and calculated by comparing the weight pre- and post-ignition (Heiri et al., 2001; Veres, 2002). Organic content was converted to carbon density by assuming $50 \%$ carbon (see Turunen et al., 2002). Samples from Sureanu (SUR; Longman et al., 2017a) and Mohos (MOH; Longman et al., 2017b) were analysed at the University of Northumbria. Samples from Baia Vulturilor (BVU), Zănoaga Roşie (ZNG), Despotovac (DES), Mluha (MLH), and Iezerul Mare (IZM) were analysed at the Institute for Speleology, Romanian Academy in Cluj-Napoca, whereas samples from Crveni Potok (CP; Finsinger et al., 2017) were analysed at the University of Montpellier. Carbon accumulation rates (CARs) were calculated by dividing the carbon content of each sample by the modelled peat accumulation rate following Ratcliffe et al. (2020) (Fig. 2).

To estimate the size of the carbon sink represented by the bogs studied, we calculate long-term apparent carbon accumulation rates (LORCA) (Clymo et al., 1998; Turunen et al., 2002) and the amount of carbon stocked by the bogs. LORCA (the cumulative carbon in the core divided by the basal age) is calculated by multiplying the median carbon (C) content by the median density and the depth of the peat accumulation, before dividing the obtained value by the basal age of the bog. This provides a first-order estimate of the rate at which each bog accumulated carbon on a long-term scale and can be used to calculate the carbon stock (in gigatonnes, $\mathrm{Gt}$ ), represented by each bog using the following equation:

$\mathrm{C}$ stock $(\mathrm{Gt})=(A \times h) \times \bar{\rho} \times \bar{c} / 10^{9}$,

where $A$ is the peatland area (in $\mathrm{km}^{2}$ ), $h$ is the peat depth (in $\mathrm{cm}), \bar{\rho}$ is the median peat density (in $\mathrm{g} \mathrm{cm}^{-3}$ ), and $\bar{c}$ is the median carbon content (in \%) (Page et al., 2011). As we do not account for decomposition, all rates presented here (e.g. LORCA; the apparent recent rate of carbon accumulation, RERCA; and CAR) are apparent and are not calculated from a net carbon balance.

\subsection{Statistical analysis}

To investigate the time series data generated by this approach, we use change-point modelling (Gallagher et al., 2011). This allows for the inference of statistically significant shifts in the dataset, meaning we can better investigate the drivers of change. To investigate the impact of past climate and moisture variability on the CARs of individual sites during discreet periods, we calculate average CARs for three periods of interest with respect to both climate and human impact: the Roman Warm Period (RWP; 2200-1550 years BP), the Medieval Warm Period (MWP; 950-1250 CE), and the Little Ice Age (LIA; 1300-1850 CE). We also calculated the apparent recent rate of carbon accumulation (RERCA) for the period from 50 years BP to present (Table 1). However, the RERCA values should be treated with caution because CAR values in the uppermost layers of peat may vary due to the exponential nature of peat decay (Clymo et al., 1998; Young et al., 2019). Further, the resolution of radiocarbon dating for the most recent 100 years is too low for meaningful conclusions for a number of the bogs. Therefore, we also quantified the amount of carbon accumulation for the past 1000 years (see Table 2 for all average values) following Gallego-Sala et al. (2018), and we focus our discussion on longer-term CAR variability.

To estimate the total size of peatland carbon sink in the Romanian Carpathians, which were selected due to the availability of data on peatland extent, we used the mean carbon content and the mean bulk density from the eight peat bogs, and the total bog area and bog depth from Pop (1960), and applied Eq. (1) to these data. To account for uncertainties, we used 1 standard deviation for our new data and applied a $10 \%$ error to Pop (1960) prior to estimating the peatland carbon sink with Monte Carlo simulations (Table S2). Repeat Monte Carlo simulations $(n=10000)$ were employed to estimate each of the variables, using the "truncnorm" $\mathrm{R}$ package, and boundaries are dictated by the data (Fig. S9).

\subsection{Composite CAR record and data-model comparison}

To interpret the effect of past hydroclimatic drivers on the Romanian Carpathian mountain peatlands, we synthesize all datasets, resulting in a representative record of CAR across the middle and late Holocene in the region (Fig. 3). To achieve this, for each individual site, we bin all data at 50year intervals. For these bins, we consider the 25 years either side of the bin age (i.e. the 0 years BP bin covers the period 26 to -25 years $\mathrm{BP}$ ). To allow for comparison across sites, we convert these raw binned CAR data into $z$ scores. We then calculate the mean and standard deviation values for each of the bins, for all studied sites. This approach allows for the interpretation of large-scale changes in CAR for a region across a long time period. As individual CARs are highly variable, with numerous stochastic and site-specific forcing factors, averaging multiple records provides insights into broad-scale factors controlling regional CARs (Loisel et al., 2021; Marlon et al., 2016).

To compare our composite CAR output to modelled palaeoclimatic indices, we use data from PaleoView (Fordham et al., 2017). We extracted six parameters related to past 


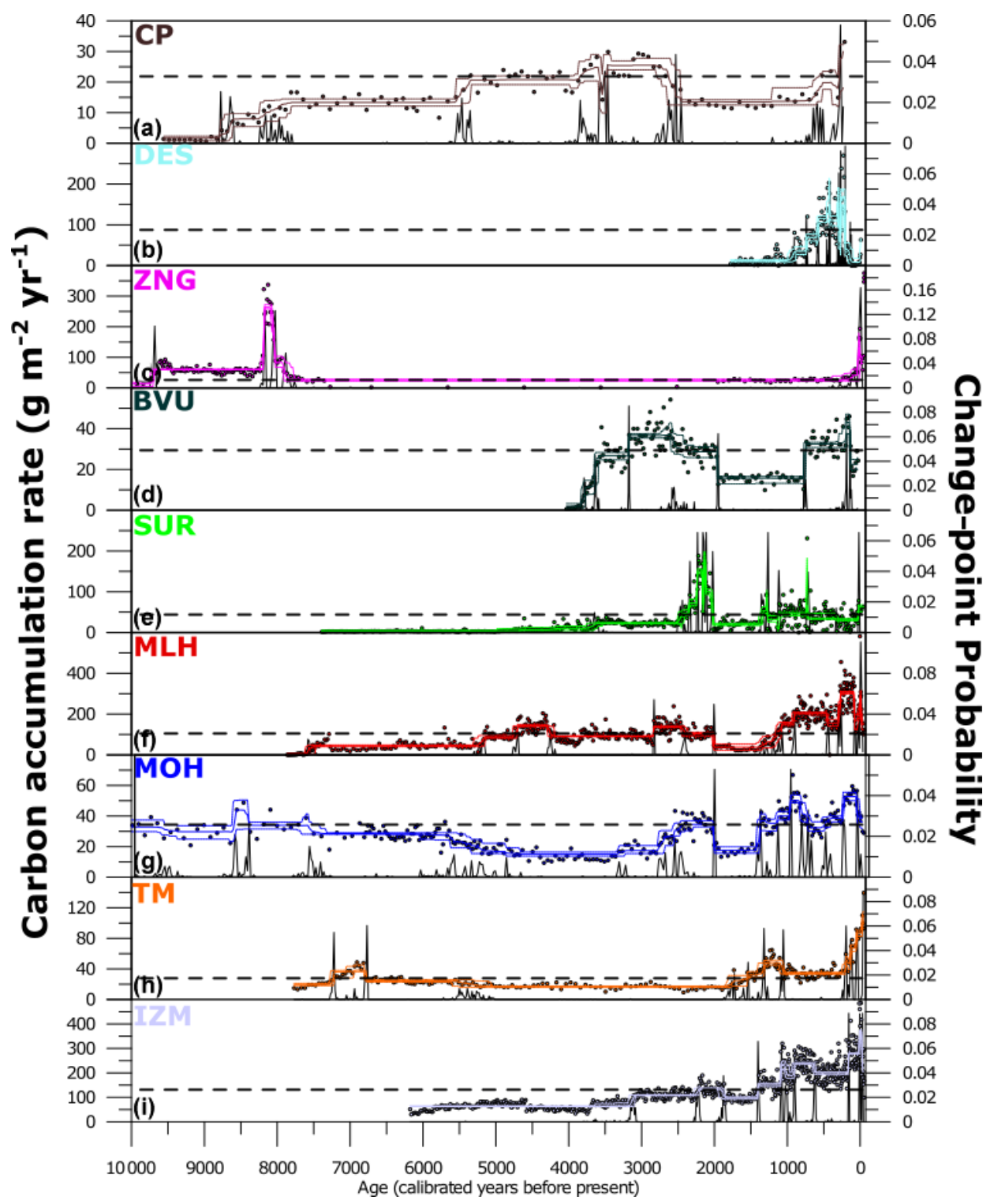

Figure 2. Changing carbon accumulation rates (CARs) through time for all of the sites in this study, and the results of change-point modelling. Each panel denotes a single peat bog CAR record, moving south to north: (a) Crveni Potok (CP), (b) Despotovac (DES), (c) Zănoaga Roşie (ZNG), (d) Baia Vulturilor (BVU), (e) Sureanu (SUR), (f) Mluha (MLH), (g) Mohos (MOH), (h) Tăul Muced (TM), and (i) Iezerul Mare (IZM). In each panel, individual measurements are denoted by filled circles. Change-point model outputs are shown by the solid coloured line, which indicates the mean and the $5 \%$ and $95 \%$ percentiles. The horizontal dashed lines indicate the long-term carbon accumulation (LORCA) values. In each panel, the black solid line denotes the likelihood of change-point occurrence.

precipitation and temperature variability from PaleoView, with each temperature variable expressed as a $z$ score relative to recent (i.e. present day set as $1975 \mathrm{CE}$, or -25 years $\mathrm{BP}$, in the model). For each variable, we use the mean area extracted from the region $40-47.5^{\circ} \mathrm{N}, 17.5-27.5^{\circ} \mathrm{E}$, which covers all sites in this study (Fig. 1).

To investigate the effect of other potential drivers, we compare the composite output to three measures of human impact and land use (population, area of pasture, and area of cropland) derived from the History Database of the Global En- vironment (HYDE) dataset (Goldewijk et al., 2017). Due to the nature of the dataset, we use the "Central Europe" region, as it contains both Romania and Serbia (Goldewijk et al., 2017). We also explore an estimate of the intensity of land use in the region, from Kaplan et al. (2011), which represents a proportion of the $5^{\circ}$ grid square (centred on $46^{\circ} \mathrm{N}$, $24^{\circ}$ E) utilized for any type of human activity on the landscape. To investigate the impact of dust deposition, we used two regionally representative reconstructions of dust deposition through the Holocene, from MOH (Longman et al., 
Table 2. Average carbon accumulation rates for a selection of time periods (in $\mathrm{g} \mathrm{Cm}^{-2} \mathrm{yr}^{-1}$ ). Also displayed are the LORCA values and an estimate of carbon storage. See the text for details.

\begin{tabular}{|c|c|c|c|c|c|c|c|c|}
\hline Peat bog & Code & $\begin{array}{r}\text { RERCA } \\
\text { (50 years BP } \\
\text { to present })\end{array}$ & $\begin{array}{r}\text { Gallego-Sala } \\
\text { approach } \\
(1000-100 \\
\text { years BP })\end{array}$ & $\begin{array}{r}\text { Medieval } \\
\text { Warm } \\
\text { Period } \\
(1000-700 \\
\text { years BP) }\end{array}$ & $\begin{array}{r}\text { Little } \\
\text { Ice } \\
\text { Age } \\
(650-100 \\
\text { years BP) }\end{array}$ & $\begin{array}{r}\text { Roman } \\
\text { Warm } \\
\text { Period } \\
(2200-1550 \\
\text { years BP })\end{array}$ & $\begin{array}{r}\text { LORCA } \\
\left(\mathrm{g} \mathrm{Cm}^{-2} \mathrm{yr}^{-1}\right)\end{array}$ & $\begin{array}{r}\text { Estimate } \\
\text { of C } \\
\text { storage } \\
(\mathrm{Gt})\end{array}$ \\
\hline Crveni Potok & $\mathrm{CP}$ & & 29.89 & 41.19 & 20.85 & 47.77 & 20.99 & 0.00004 \\
\hline Despotovac & DES & 15.39 & 74.18 & 35.46 & 96.94 & 7.57 & 81.11 & 0.00000 \\
\hline Zănoaga Roşie & ZNG & 159.61 & 27.06 & 24.99 & 28.58 & 17.36 & 17.12 & 0.00021 \\
\hline Baia Vulturilor & $\mathrm{BVU}$ & 26.67 & 29.34 & 20.44 & 33.19 & 21.79 & 28.08 & 0.00011 \\
\hline Sureanu & SUR & 51.59 & 40.80 & 49.60 & 34.61 & 58.50 & 37.45 & 0.00000 \\
\hline Mluha & MLH & 228.56 & 217.67 & 191.24 & 235.78 & 74.03 & 91.74 & 0.00007 \\
\hline Mohos & $\mathrm{MOH}$ & 39.29 & 42.18 & 46.45 & 40.88 & 25.32 & 32.61 & 0.00028 \\
\hline Tăul Muced & $\mathrm{TM}$ & 96.45 & 37.02 & 33.99 & 39.28 & 19.22 & 24.32 & 0.00000 \\
\hline Iezerul Mare & IZM & 283.45 & 217.47 & 224.64 & 211.18 & 115.57 & 120.59 & 0.00007 \\
\hline
\end{tabular}

2017b) and TM (Panait et al., 2019). Furthermore, to explore the impact of biomass burning on the record, we compare it with the compilation of eastern European charcoal deposition from Feurdean et al. (2020), from which we extract the boreal (BOR) record, as this covers all sites in this study. We used linear interpolation to bring all datasets onto a 50-year timescale for comparison with our binned composite CAR record.

\section{Results}

\subsection{Basic peat bog information}

Where possible, the basal peat layer was reached, allowing for a reliable estimate of the total $\mathrm{C}$ stock. This varied from $940 \mathrm{~cm}$ at $\mathrm{MOH}$ to $193 \mathrm{~cm}$ at BVU, reflected in variable accumulation rates among records (Table 1). For example, ZNG in the Semenic Mountains, containing a long hiatus or very low accumulation rates in peat accumulation, yielded accumulation rates (ARs) as low as $0.02 \mathrm{~cm} \mathrm{yr}^{-1}$. In contrast, IZM and DES displayed ARs of greater than $0.1 \mathrm{~cm} \mathrm{yr}^{-1}$, corresponding to ca. $800 \mathrm{~cm}$ of peat deposition in ca. 6200 years at IZM and ca. $200 \mathrm{~cm}$ in $\sim 2000$ years at DES (Table 1). The lowest average density is $0.07 \mathrm{~g} \mathrm{~cm}^{-3}$ at MOH (see Fig. S10), reflecting the pure Sphagnum moss composition of the peat stock. In contrast, the highest density is observed at DES $\left(0.35 \mathrm{~g} \mathrm{~cm}^{-3}\right)$, where minerogenic material has been delivered to the mire from the surrounding slopes impacted by agriculture; see Fig. S11 for minerogenic matter from all bogs. In terms of median carbon content, all records show values around $50 \% \mathrm{C}$ other than DES, where minerogenic input leads to a $\mathrm{C}$ content of ca. $20 \%$ (Table 1). The highest median $\mathrm{C}$ values are recorded at $\mathrm{ZNG}$, where $\mathrm{C}$ represents $49.6 \%$ of the peat content (Fig. S12).
3.2 LORCA, CARs for different periods, and estimates of total carbon storage

Calculations of LORCA indicate a wide range of longterm carbon accumulation between records. The lowest LORCA values are from ZNG $\left(17 \mathrm{~g} \mathrm{Cm}^{-2} \mathrm{yr}^{-1}\right)$ and CP $\left(21 \mathrm{~g} \mathrm{C} \mathrm{m}^{-2} \mathrm{yr}^{-1}\right)$, the latter of which is a slowly accumulating bog. In contrast, the highest LORCA values are reconstructed from the mountain bogs MLH and IZM, with values of 92 and $121 \mathrm{~g} \mathrm{Cm}^{-2} \mathrm{yr}^{-1}$ respectively (Table 2). When combined with estimates of the thickness and spatial extent of the bogs, we can calculate total carbon storage in each location. Of our studied locations, $\mathrm{MOH}$ contains the most carbon, with an estimate of $0.0003 \mathrm{Pg} \mathrm{C}$, whereas the remainder of the sites contain between 0.00005 and $0.0001 \mathrm{PgC}$ (Table 2).

CARs for the Roman Warm Period (RWP) vary from $8 \mathrm{~g} \mathrm{Cm}^{-2} \mathrm{yr}^{-1}$ at DES to $74 \mathrm{~g} \mathrm{Cm}^{-2} \mathrm{yr}^{-1}$ at MLH, with the majority of sites between 15 and $25 \mathrm{~g} \mathrm{Cm}^{-2} \mathrm{yr}^{-1}$ (Table 2). For the Medieval Warm Period (MWP), the lowest average CAR is $20 \mathrm{~g} \mathrm{Cm}^{-2} \mathrm{yr}^{-1}$ at BVU, with MLH displaying the greatest CAR $\left(191 \mathrm{~g} \mathrm{C} \mathrm{m}^{-2} \mathrm{yr}^{-1}\right)$. For the LIA, values range from 21 (CP) to $236 \mathrm{~g} \mathrm{Cm}^{-2} \mathrm{yr}^{-1}$ (MLH). For the period from 1000 to 100 years BP, all values other than MLH are between 25 and $75 \mathrm{~g} \mathrm{Cm}^{-2} \mathrm{yr}^{-1}$. The RERCA calculations indicate CARs between 15 and $50 \mathrm{~g} \mathrm{C} \mathrm{m}^{-2} \mathrm{yr}^{-1}$ for most sites, but IZM $\left(121 \mathrm{~g} \mathrm{Cm}^{-2} \mathrm{yr}^{-1}\right)$ and MLH $\left(92 \mathrm{~g} \mathrm{Cm}^{-2} \mathrm{yr}^{-1}\right)$ are well above that range (Table 2).

\subsection{Carbon accumulation rates throughout the Holocene}

For each site, we developed a time series displaying how CARs varied through the Holocene and combined them into a composite time series (Fig. 3) that shows changes in $\mathrm{CAR}$ at broader spatial scales. For the period from 7000 to 4000 years BP, $z$ scores show a slow decrease until a low 


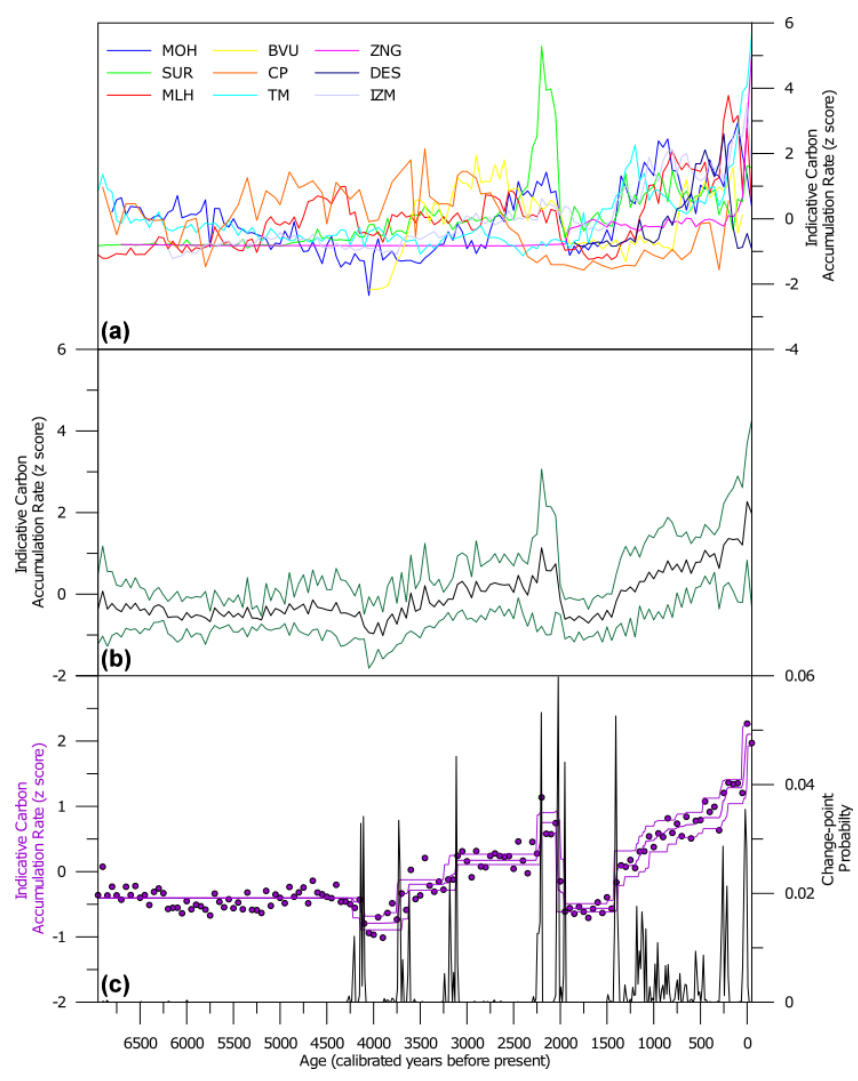

Figure 3. Collated normalized carbon accumulation rates, and the composite of data. Panel (a) displays the 50-year binned, $z$-scoreconverted raw data from each site. Panel (b) shows the synthesis of all of the data in panel (a), with the mean $z$ score indicated using a solid black line. The green lines denote 1 standard deviation. Panel (c) displays the change-point modelling of the composite time series. Filled circles indicate data points. Change-point model outputs are shown with the solid purple line indicating the mean and the dashed purple lines indicating the $5 \%$ and $95 \%$ percentiles. The black solid line denotes the likelihood of change-point occurrence.

point of -1 by 4000 years BP. This is followed by rapid and sustained increases in CARs, reaching a value of 1 by 2100 years BP, primarily driven by the large rise in CAR at SUR during this time (Fig. 3). This is followed by a rapid drop to a period of low values between 2000 and 1300 years $\mathrm{BP}$, before another sustained period of increasing CARs between 1500 years BP and present (Fig. 3).

\section{Discussion}

\subsection{Long-term carbon accumulation and an estimate of the Carpathian peatland carbon sink}

Our data indicate that CAR rates vary greatly, both spatially and temporally, in the Carpathian Mountains (Figs. 2, 3). Our LORCA estimates also reflect this trend, with slow-growing peat bogs such as $\mathrm{CP}$ accumulating peat at an average of
$21 \mathrm{~g} \mathrm{Cm}^{-2} \mathrm{yr}^{-1}$, whereas quickly accumulating records such as IZM reach LORCA values as high as $121 \mathrm{~g} \mathrm{Cm}^{-2} \mathrm{yr}^{-1}$ (Table 2). IZM and MLH display some of the highest LORCA values reported in the literature (Loisel et al., 2014) and indicate that raised ombrotrophic mountain bog environments may be extremely effective carbon sinks. This is supported by comparable LORCA values from bogs in the Andes, where they may reach $250 \mathrm{~g} \mathrm{Cm}^{-2} \mathrm{yr}^{-1}$ (Chimner and Karberg, 2008), and the Falkland Islands (Payne et al., 2019). Furthermore, eddy covariance data regularly indicate carbon accumulation rates greater than $100 \mathrm{~g} \mathrm{Cm}^{-2} \mathrm{yr}^{-1}$ (e.g. Roulet et al., 2007). Typical lowland bogs sequester carbon at rates of below $30 \mathrm{~g} \mathrm{Cm}^{-2} \mathrm{yr}^{-1}$ (Loisel et al., 2014); thus, rates of over $100 \mathrm{~g} \mathrm{C} \mathrm{m}^{-2} \mathrm{yr}^{-1}$ are notably high. Indeed, such high CARs are similar to measurements of recent peat accumulation rates which have not been corrected for peat decomposition (Young et al., 2019). It is possible that the location of some mountain bogs at the base of scree slopes means that these bogs could be well supplied with regards to nutrients via minerogenic input, such as for SUR (Longman et al., 2017a, 2019). This is analogous to nutrients supplied from volcanic ash deposition, which has been observed to stimulate greater peat accumulation in bogs in New Zealand (Ratcliffe et al., 2020) and Japan (Hughes et al., 2013). In other locations, such as the true raised bogs MLH, IZM, and $\mathrm{MOH}$, or blanket bogs BVU and ZNG, a more likely explanation is that the frequency of long-term atmospheric dust deposition in the Carpathian region (Longman et al., 2017b; Panait et al., 2019; Varga et al., 2013, 2016) helps to supply nutrients, which is a process known to stimulate considerable peat growth (Kylander et al., 2018). In each potential scenario, nutrients would likely be supplied in pulses, which have been shown to be important for peat growth (Schillereff et al., 2021).

We use our measurements of carbon content and peat density in combination with published estimates of the extent of Romanian Carpathian peatlands to estimate the size of this regional carbon sink (Table S2; Pop, 1960). In Pop (1960), Carpathian peatlands were separated into two main types: oligotrophic (primarily raised bogs, covering ca. $15 \mathrm{~km}^{2}$, with an average depth of $\sim 2 \mathrm{~m}$ ) and eutrophic (including fens and marshes, covering ca. $60 \mathrm{~km}^{2}$, with an average depth of $1 \mathrm{~m}$ ). It must be noted that this estimate only includes bogs located in the Carpathian Mountains and does not include the extensive lowland wetlands of areas like the Danube Valley and its delta (Pop, 1960).

Our modelling suggests that oligotrophic bogs, the class in which most mountain bogs fall, represent a mean carbon sink of $2 \mathrm{Mt} \mathrm{C}$ (megatonnes of carbon) in the Romanian Carpathians, with the uppermost models (95th percentile) indicating that $10 \mathrm{MtC}$ is stored. Eutrophic bogs represent a mean carbon sink of $4 \mathrm{MtC}$, with the 95 th percentile at $0.008 \mathrm{GtC}$. Combined, the peatland sink of the Romanian Carpathians most likely comprises a value of $6 \mathrm{MtC}$, reaching $0.012 \mathrm{Gt}$ in the 95th percentile of models (Fig. 5). It should be noted 


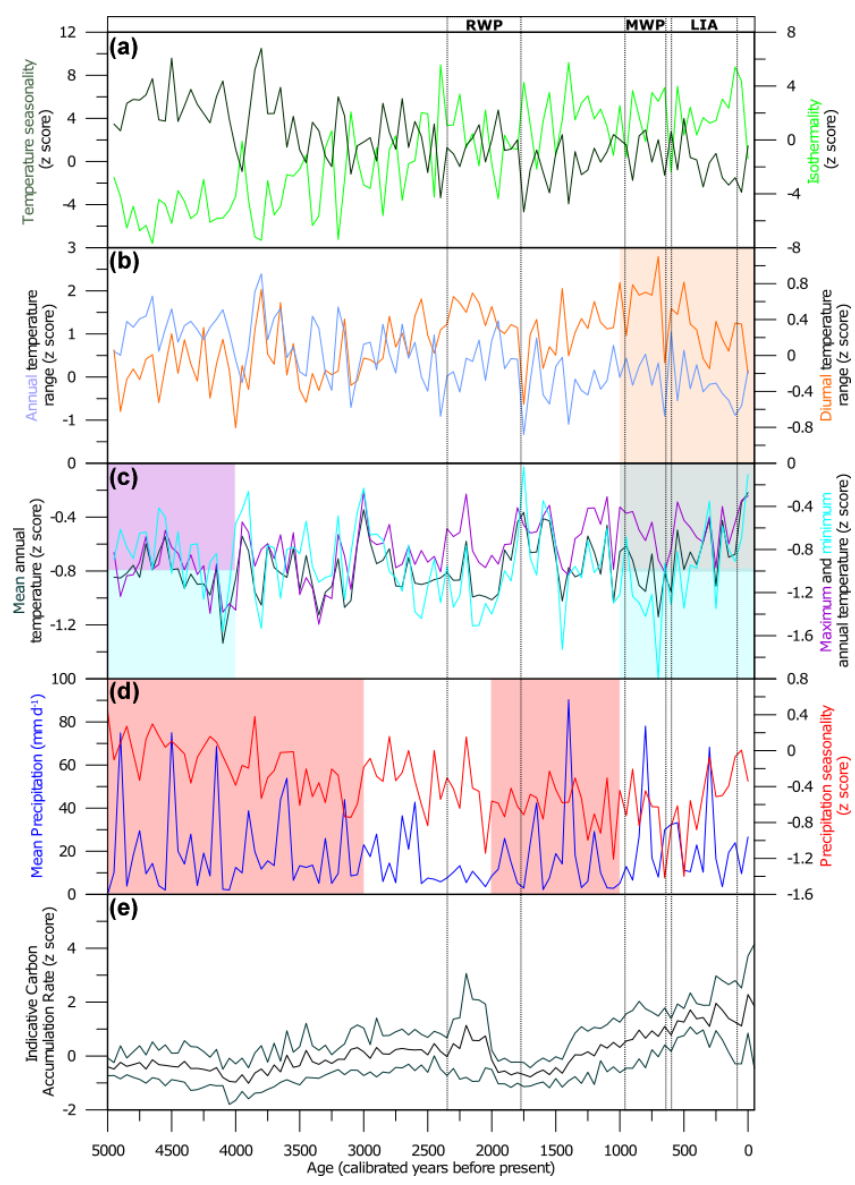

Figure 4. Comparison of the carbon accumulation rate (CAR) composite with climatic variables as extracted from our modelling approach. Panels (a)-(d) show the climate variables in this study used for the comparison with the reconstructed CAR for central-eastern Europe shown in panel (e). Coloured rectangles highlight the 1000year periods in which a statistically significant correlation between CAR and the variable of that colour are observed (e.g. precipitation seasonality and CAR in the period from 1950 to 1000 years BP in panel d). When two variables significantly correlate with CARs, both colours are indicated using rectangles (e.g. correlation of mean and minimum temperature with CAR in the period from 1000 years BP to present in panel c). The Roman Warm Period (RWP), the Medieval Warm Period (MWP), and the Little Ice Age (LIA) are also indicated using vertical dashed lines.

that this upper estimate is 4 times the amount of carbon sequestered by forests in Romania per year $\left(2.5 \mathrm{MtC} \mathrm{yr}^{-1}\right)$ (Olofsson et al., 2009) and represents $13 \%$ of the yearly Romanian anthropogenic carbon emissions (ca. $80 \mathrm{MtC} \mathrm{yr}^{-1}$ ) (Crippa et al., 2021). In isolation, these estimates of mountain bogs comprise a small proportion (ca. $0.002 \%$ ) of the global peatland carbon sink (roughly $600 \mathrm{Gt}$ ), with individual tropical wetland areas comprising carbon stores that are orders of magnitude greater (Dargie et al., 2017; Warren et al., 2017). However, the rapid nature of carbon accumulation in the Carpathian bogs studied here, as well as in other

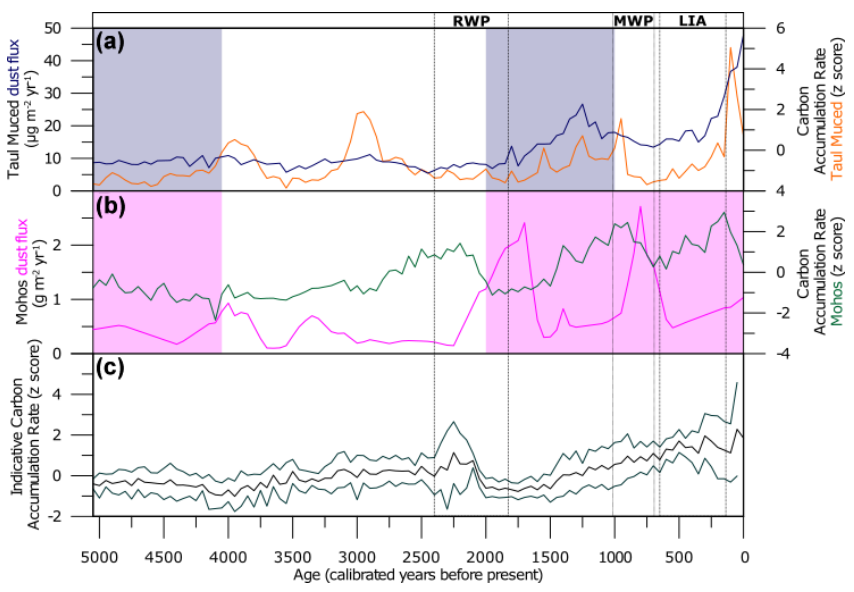

Figure 5. Comparison of dust fluxes and our reconstruction of the carbon accumulation rate (CAR). Panel (a) shows the dust flux reconstructed from Tăul Muced as well as the corresponding CAR. Panel (b) shows the dust flux reconstructed from Mohos as well as the corresponding CAR. Panel (c) shows the CAR composite record. Coloured rectangles indicate a significant correlation between the variable indicated by the colour and the CAR reconstruction, as in Fig. 4. The Roman Warm Period (RWP), the Medieval Warm Period (MWP), and the Little Ice Age (LIA) are also indicated using vertical dashed lines.

mountainous regions such as Tibet (Chen et al., 2014), suggests that they may be more efficient sinks than tropical bogs, which accumulate more slowly and decompose more quickly (e.g. Dargie et al., 2017; Hapsari et al., 2017).

\subsection{Changing rates of carbon accumulation during the Holocene}

By investigating the change-point models of each individual peatland CAR as well as the composite CAR record, we explore changing rates of accumulation through the Holocene (Figs. 2, 3). In the studied region, three peatlands (CP, MOH, and ZNG) were established in the early Holocene (100007000 years BP). For this period, average CARs are above the LORCA of each bog (see Fig. 2), indicating rapid accumulation. This is in agreement with other studies of European peatlands (Ratcliffe et al., 2018), where rapid CARs are reconstructed in the early Holocene as a result of warm temperatures; this is a reflection of the key role that temperature plays in CARs (Charman et al., 2009). Regionally, our data reflect the impact of warmer-than-present conditions and lower-than-present precipitation levels as well as higher seasonality reconstructed from multi-proxy records (Buczkó et al., 2013; Davis et al., 2003; Feurdean et al., 2008; Magyari et al., 2009; Tóth et al., 2015, 2018) and modelled data which coincided with higher-than-present (summer) insolation (Berger and Loutre, 1991).

During the mid-Holocene (7000-3000 years BP), CARs were generally low, with our composite record reconstruct- 
ing a decreasing trend until 4000 years BP (Fig. 3) and supported by a series of negative change-points in individual records (Figs. 2, 3). CAR rates for this period are below the LORCA for all sites (Fig. 2), indicating a period of slow peat growth on a regional scale. This may be linked to colder and wetter-than-present climatic conditions which progressively established in the region (Davis et al., 2003; Feurdean et al., 2008; Perşoiu et al., 2017), following a peak in temperatures prior to 8500 years BP (Tóth et al., 2015). Cooler conditions and higher lake levels are reconstructed from chironomid records from different parts of the Southern Carpathians (Tóth et al., 2015), while pronounced depositional changes and increased lake levels are observed in both the eastern and western Romanian Carpathians (Haliuc et al., 2017; Magyari et al., 2009); moreover, fluvial records indicate greater river flows (Persoiu, 2010). Around 5000 years BP, a major shift in atmospheric circulation towards a variable North Atlantic oscillation index is shown in water isotope data from Scărişoara Cave (Romania; Perşoiu et al., 2017), reflecting continental-scale changes (Olsen et al., 2012). This coincides with changes in insolation, with strong contrasts between December and June insolation (Berger and Loutre, 1991).

At ZNG, peat accumulation ceased almost entirely for this period (Fig. 2), and BVU started accumulating peat only after 4000 years BP, reflecting the extent to which cold environmental conditions impacted CARs in the Southern Carpathians. The local nature of CAR responses, however, may indicate local climatic variability, with peat CARs stable at higher elevation (SUR) and even rising at slightly lower elevation (MLH) during this time (Fig. 2). In our composite record, the lowest levels of carbon accumulation are reflected in the period from 4200 to 3800 years BP, which coincides with the $4.2 \mathrm{ka}$ event (Fig. 4). This was a roughly 100 -yearlong period of Europe-wide dry and cool climate (Bini et al., 2019), reflected in the Carpathians by increased dust deposition (Longman et al., 2017b) and evidence of cold and dry (winter) conditions (Constantin et al., 2007; Drăguşin et al., 2014; Perşoiu et al., 2019; Tóth et al., 2015), which appear to have led to region-wide decreases in peat growth (Figs. 2, 3). However, short-term local increases in precipitation are reconstructed in a mid-latitude lake record (Haliuc et al., 2017) and in low-altitude fluvial records (Howard et al., 2004). These conclusions are supported by other parameters such as chironomid-based summer temperatures and testate-amoebaderived measures of wetness (Onac et al., 2002; Schnitchen et al., 2006; Tóth et al., 2015). These contrasting trends reflect seasonal responses to changing local moisture sources, not only in the Carpathians but also throughout the Balkans (Haliuc et al., 2017; Perşoiu et al., 2019), indicating the particularities and dynamics of the regional climatic variability in southeastern Europe (see Haliuc et al., 2017, 2020; Longman et al., 2019).

After this period of low carbon accumulation, CARs rebounded, with widespread increases observed and a series of positive change-points recorded, notably at $\mathrm{MOH}$, SUR,
IZM, and, CP, from 3000 years BP onwards (Fig. 2). This is reflected by a rapid increase in our composite of CAR measurements, where a long-term CAR increase is reconstructed between 3400 and 2000 years BP (Fig. 4). It is possible this is linked to higher variability in the climatic conditions during this period, as evidence suggests that the period from 3500 to 2000 years BP was generally cool and wet across the region (Magyari et al., 2009; Schnitchen et al., 2006; Tóth et al., 2015). The specific atmospheric circulation regime of the Carpathians (Haliuc et al., 2017; Longman et al., 2017a), which drives significant lateral hydrological variability across the wider region (Longman et al., 2019; Magyari et al., 2013), may explain why some pollen-based climatic indices suggest a warming between 3000 and 2400 years BP (Feurdean et al., 2008), and carbon isotopes in peat indicate high climatic variability (Cristea et al., 2013). However, instead of considering only a climatic control on CARs over this period, it is possible that the increasing impact of human activity on the region (Longman et al., 2017a) contributed to the contradictory proxy reconstructions of climate at this time, with vegetation-based climate reconstructions potentially impacted by anthropogenic disturbances (Chevalier et al., 2020; Finsinger et al., 2010).

A steady increase in land use in the Carpathian area has been reconstructed for the last 7000 years using modelled deforestation rates (Giosan et al., 2012). Since 3000 years $\mathrm{BP}$, increasing land use has been demonstrated, tracking demographic variability (Kaplan et al., 2011). Enhanced land use and tree felling in the mid- to high-mountain environments (Hughes and Thirgood, 1982; Longman et al., 2017a) would have increased erosion (Longman et al., 2019), with increased erosion observed in lake records from the Balkans at this time (Wagner et al., 2012), and the onset of minerogenic input to the SUR bog (Longman et al., 2017a). Greater erosion would have resulted in an increased nutrient supply, thereby stimulating peat growth in a similar manner to the increased deposition of mineral dust (Kylander et al., 2018) or volcanic ash (Ratcliffe et al., 2020). This hypothesis is supported by the decreasing CARs reconstructed after 2000 years BP during the Migration period, denoting lower levels of land use and less anthropogenic disturbance of the environment (Kaplan et al., 2011; Longman et al., 2018).

The period of low CARs (2000-1300 years BP) is followed by a series of positive change-points and a gradual rise in the composite CAR record until the present day (Figs. 2, 3 ). The climate during this interval was characterized by a warming trend in both summer and winter temperatures but with regionally specific hydroclimate patterns (Perşoiu and Perşoiu, 2019). The lack of any relationship between CARs and the apparent warmth of the RWP (2200-1500 years BP) and MWP (1000-700 years BP) and the cool LIA (650100 years BP) in the region further support the theory that peat accumulation rates were impacted by human activity (Fig. 3, Table 2). Indeed, at six of our nine sites, the LIA displays higher CARs than during the MWP, despite the ap- 
parent controlling nature of temperature change on peat accumulation (Charman et al., 2013, 2015). This may be a feature of the low-latitude nature of our sites where, unlike Arctic sites where low temperatures and high moisture lead to lower CARs, lower temperatures and high moisture stimulate peat growth. However, it is also possible that the lack of any correlation is due to the variable expression of these transient periods of climatic change (MWP and LIA) on the climate of central-eastern Europe (Roberts et al., 2012; Magyari et al., 2013). There is evidence which suggests that the climate in southeastern Europe over the last 1000 years did not mirror that of western Europe, with a lack of correlation between tree-ring-derived summer temperatures in the Eastern Carpathians (Popa and Kern, 2009) and central European records (Buntgen et al., 2011). This is further supported by the disconnect between southeastern European pollen reconstructions of temperature and those from central and western Europe in the Holocene (Davis et al., 2003; Mauri et al., 2015). However, other work suggests that the MWP was indeed warm and dry in Romania (Feurdean et al., 2011), whereas the LIA was cooler overall (Cleary et al., 2018), with regional expressions of hydroclimate variability. For the MWP, contrasting hydroclimate conditions are reconstructed from records across Romania. Warm and dry conditions are evident in records from the north and northwest Romanian Carpathians (Cleary et al., 2018; Cristea et al., 2013; Forray et al., 2015; Popa and Kern, 2009), whereas records in the northern, southern, and eastern regions of the Carpathians show wet conditions (Diaconu et al., 2017; Feurdean et al., 2015; Gałka et al., 2016; Panait et al., 2017, 2019). These apparently contrasting results further indicate the complexity of climate in the region, due to its location at the confluence of three major atmospheric systems (Longman et al., 2017b; Obreht et al., 2016). As such, the range of CARs may be the result of still unexplored local hydroclimatic gradients. As a result, unpicking exactly which features of a climatic record in central-eastern Europe may be attributed to climatic forces and which may be related to human impacts remains a challenge.

\subsection{Data-model comparison}

One way in which potential drivers of change in peat accumulation may be elucidated is by comparing our data to model reconstructions of climatic variables, such as temperature and precipitation, and investigating their relationship with the observed shifts in CAR (Fig. 4). Here, we compare the results of our composite record (binned at a 50-year resolution) to a number of climatic indices extracted at 50year time steps from modelling reconstructions of the last 5000 years (Fordham et al., 2017).

When comparing the full datasets, several statistically significant correlations are revealed (Table 3, Fig. 4). These include both temperature and precipitation seasonality and diurnal and annual temperature range (Table 3). Strong nega- tive correlations between both precipitation and temperature seasonality and CARs indicate that CARs decrease as seasonality increases. This is in direct contrast to high-latitude bogs from Alaska, where it has been shown that increased seasonality during the middle Holocene led to higher CARs (Jones and Yu, 2010). The anticorrelation that we observed here suggests that seasonality and implied higher summer temperatures, which are proposed to be the drivers of carbon accumulation in Alaska, are less important in more temperate bog locations, potentially explaining the apparently incongruous (high CAR) response to cold conditions during the LIA (Figs. 2, 3, 4). This is supported by the strong negative correlation between the annual temperature range and CARs (Table 3). The strongest correlation is observed between CAR and isothermality, a measure of the difference between the annual range in temperature and the diurnal (daily) range in temperature (O'Donnell and Ignizio, 2012). In the Carpathians, a strong isothermality leads to high CARs, which is in line with measurements of carbon flux from peatlands, where strong isothermality has been linked to the shift of a bog to a net carbon sink (Webster et al., 2018). This may be related to the strong impact that isothermality has on bryophyte distributions, with some evidence suggesting that range expansion of some species may occur under increasingly greater isothermality, especially in humid regions (Kou et al., 2020).

To investigate the impact of long-term hydroclimate variability on CARs, we separate the model outputs into five 1000-year sections compared with the composite record CARs for the same period (Table 3). From this exercise, the strongest agreements appear between hydroclimate and CAR in the period from 5000 to 4000 years BP, with statistically significant correlations between CARs and the seasonality of precipitation, mean temperature, and maximum temperature respectively. The strongest correlation is with maximum temperature (Fig. 4), supporting previous evidence that the strongest control on peat growth in this region in the preanthropogenic world has been linked to temperature variability (Charman et al., 2013, 2015). Laboratory and fieldbased experiments have shown this to be the case, with higher temperatures leading to the growth of larger Sphagnum plants as well as an increase in the amount of biomass produced (Asada et al., 2003; Breeuwer et al., 2008; Gunnarsson, 2005). In Romania, temperature was listed as the most important climatic variable for peat growth, as it led to the development of Sphagnum-dominated high-biomass peat for the TM record, rather than sedge-dominated peat (Panait et al., 2017). Strong correlations also exist between PAR0, a measure of photosynthetically active solar radiation, and Sphagnum growth (Loisel et al., 2012). The correlation with precipitation seasonality is also in line with previous work, which has suggested that the availability of moisture during the growing season is a key control on peat growth (Jassey and Signarbieux, 2019; Oke and Hager, 2017), with seasonality linked to the total peat carbon stock preserved (Kurnianto 
Table 3. Correlation coefficients and $p$ values between the bioclimatic parameters of climate change and the reconstructed carbon accumulation rates, for a selection of time periods. The $p$ values significant at the 0.05 level are highlighted in bold, whereas those significant at the 0.01 level are italicized.

\begin{tabular}{|c|c|c|c|c|c|}
\hline & Pearson's $r$ & $p$ value & & arson's $r$ & $p$ value \\
\hline \multicolumn{3}{|c|}{ Whole period (5000 years BP to present) } & \multicolumn{3}{|c|}{ 2950-2000 years BP } \\
\hline Mean precipitation & 0.017 & 0.87 & Mean precipitation & -0.168 & 0.46 \\
\hline Precipitation seasonality & -0.326 & $<0.01$ & Precipitation seasonality & 0.038 & 0.87 \\
\hline Mean temperature & 0.141 & 0.16 & Mean temperature & -0.025 & 0.91 \\
\hline Minimum temperature & -0.073 & 0.46 & Minimum temperature & -0.095 & 0.68 \\
\hline Maximum temperature & 0.371 & $<0.01$ & Maximum temperature & 0.264 & 0.24 \\
\hline Diurnal range & 0.339 & $<0.01$ & Diurnal range & 0.283 & 0.20 \\
\hline Annual range & -0.421 & $<0.01$ & Annual range & -0.034 & 0.88 \\
\hline Isothermality & 0.505 & $<0.01$ & Isothermality & 0.101 & 0.66 \\
\hline Temperature seasonality & -0.382 & $<0.01$ & Temperature seasonality & -0.022 & 0.92 \\
\hline \multicolumn{3}{|c|}{ 5000-4000 years BP } & \multicolumn{3}{|c|}{$1950-1000$ years BP } \\
\hline Mean precipitation & 0.304 & 0.17 & Mean precipitation & -0.169 & 0.45 \\
\hline Precipitation seasonality & 0.477 & 0.03 & Precipitation seasonality & -0.365 & 0.10 \\
\hline Mean temperature & 0.52 & 0.01 & Mean temperature & -0.258 & 0.25 \\
\hline Minimum temperature & 0.263 & 0.24 & Minimum temperature & -0.185 & 0.41 \\
\hline Maximum temperature & 0.547 & 0.01 & Maximum temperature & 0.171 & 0.45 \\
\hline Diurnal range & 0.169 & 0.45 & Diurnal range & 0.355 & 0.11 \\
\hline Annual range & 0.251 & 0.26 & Annual range & -0.061 & 0.79 \\
\hline Isothermality & -0.183 & 0.42 & Isothermality & 0.203 & 0.37 \\
\hline Temperature seasonality & 0.307 & 0.17 & Temperature seasonality & 0.143 & 0.53 \\
\hline \multicolumn{3}{|c|}{ 3950-3000 years BP } & \multicolumn{3}{|c|}{950 years BP to present } \\
\hline Mean precipitation & -0.119 & 0.60 & Mean precipitation & -0.206 & 0.36 \\
\hline Precipitation seasonality & -0.397 & 0.07 & Precipitation seasonality & 0.103 & 0.65 \\
\hline Mean temperature & -0.007 & 0.97 & Mean temperature & 0.465 & $\mathbf{0 . 0 3}$ \\
\hline Minimum temperature & 0.159 & 0.48 & Minimum temperature & 0.497 & 0.02 \\
\hline Maximum temperature & -0.179 & 0.43 & Maximum temperature & 0.12 & 0.60 \\
\hline Diurnal range & -0.326 & 0.14 & Diurnal range & -0.533 & 0.01 \\
\hline Annual range & -0.259 & 0.25 & Annual range & -0.295 & 0.18 \\
\hline Isothermality & 0.366 & 0.10 & Isothermality & -0.016 & 0.94 \\
\hline Temperature seasonality & -0.35 & 0.11 & Temperature seasonality & -0.184 & 0.41 \\
\hline
\end{tabular}

et al., 2015). In this case, we assume that the increase in seasonality results in a rise in summer precipitation, rather than winter (Fig. 4, Table 3). In addition to general climatic controls, it is also possible that smaller-term fluctuations and local configurations may impact CARs. For example, CARs of some peatlands along the St. Lawrence River in Canada are strongly impacted by the level of sheltering from cold winter winds (Magnan and Garneau, 2014). Such local climatic controls are challenging to evaluate on the scales studied here but may play a role in some of the bogs.

No further statistically significant correlations are observed during any of the three subsequent 1000 -year periods (3950-3000, 2950-2000, and 1950-1000 years BP), indicating that climate is not playing the major forcing role on peat growth through this time (Fig. 4, Table 3). Such a finding supports our earlier assertion that human impact has become a primary driver of peat growth in the Carpathians, with our data-model comparison suggesting the shift occurs after 4000 years BP, further supporting estimates of enhanced human pressure on the mid- to high-mountain environments (Giosan et al., 2012; Schumacher et al., 2016), which led to widespread soil erosion (Longman et al., 2017a).

Between 950 years BP and present, there are strong positive correlations between CAR and the mean and minimum temperatures, denoting a primarily climatic control on peat accumulation (Fig. 4, Table 4). However, the correlation in this period is driven by the last 200 years, where recent warm temperatures reflect recent high CARs (Figs. 2, 3, 4). These recent high temperatures largely reflect anthropogenic activity and climate change associated with greenhouse gas emissions, and it might be asserted that higher CAR over this period is not linked with natural climatic fluctuations but rather with an increase in human emissions. It must also be noted that it is possible that recent CAR increases are also related to 
Table 4. Correlation coefficients and $p$ values between the indicators of human impact and between dust input and the reconstructed carbon accumulation rates, for a selection of time periods. The $p$ values significant at the 0.05 level are highlighted in bold, whereas those significant at the 0.01 level are italicized.

\begin{tabular}{|c|c|c|c|c|c|}
\hline \multicolumn{2}{|c|}{ Pearson's $r$} & $p$ value & \multicolumn{2}{|c|}{ Pearson's $r$} & $p$ value \\
\hline \multicolumn{3}{|c|}{ Whole period (5000 years BP to present) } & \multicolumn{3}{|c|}{ 2950-2000 years BP } \\
\hline HYDE population & 0.584 & $<0.01$ & HYDE population & $\mathrm{n} / \mathrm{a}$ & $\mathrm{n} / \mathrm{a}$ \\
\hline HYDE cropland & 0.652 & $<0.01$ & HYDE cropland & $\mathrm{n} / \mathrm{a}$ & $\mathrm{n} / \mathrm{a}$ \\
\hline HYDE pasture & 0.881 & $<0.01$ & HYDE pasture & $\mathrm{n} / \mathrm{a}$ & $\mathrm{n} / \mathrm{a}$ \\
\hline Kaplan land use & 0.673 & $<0.01$ & Kaplan land use & -0.218 & 0.33 \\
\hline MOH dust flux and CAR composite ${ }^{a}$ & 0.042 & 0.67 & $\mathrm{MOH}$ dust flux and CAR composite ${ }^{\mathrm{a}}$ & -0.632 & $<0.01$ \\
\hline TM dust flux and CAR composite ${ }^{\mathrm{a}}$ & 0.240 & 0.02 & TM dust flux and CAR composite ${ }^{\mathrm{a}}$ & 0.658 & $<0.01$ \\
\hline $\mathrm{MOH}$ dust and $\mathrm{MOH} \mathrm{CAR}^{\mathrm{b}}$ & 0.220 & $\mathbf{0 . 0 3}$ & $\mathrm{MOH}$ dust and $\mathrm{MOH} \mathrm{CAR}^{\mathrm{b}}$ & -0.057 & 0.80 \\
\hline TM dust and TM CAR ${ }^{b}$ & 0.598 & $<0.01$ & TM dust and TM CAR ${ }^{\mathrm{b}}$ & 0.760 & $<0.01$ \\
\hline Charcoal and composite $\mathrm{CAR}^{\mathrm{c}}$ & 0.774 & $<0.01$ & Charcoal and composite $\mathrm{CAR}^{\mathrm{c}}$ & 0.369 & 0.09 \\
\hline \multicolumn{3}{|c|}{ 5000-4000 years BP } & \multicolumn{3}{|c|}{$1950-1000$ years BP } \\
\hline HYDE population & $\mathrm{n} / \mathrm{a}$ & $\mathrm{n} / \mathrm{a}$ & HYDE population & 0.480 & 0.02 \\
\hline HYDE cropland & $\mathrm{n} / \mathrm{a}$ & $\mathrm{n} / \mathrm{a}$ & HYDE cropland & 0.019 & 0.93 \\
\hline HYDE pasture & $\mathrm{n} / \mathrm{a}$ & $\mathrm{n} / \mathrm{a}$ & HYDE pasture & 0.731 & $<0.01$ \\
\hline Kaplan land use & $\mathrm{n} / \mathrm{a}$ & $\mathrm{n} / \mathrm{a}$ & Kaplan land use & -0.470 & $\mathbf{0 . 0 3}$ \\
\hline MOH dust flux and CAR composite ${ }^{\mathrm{a}}$ & -0.518 & 0.01 & $\mathrm{MOH}$ dust flux and CAR composite ${ }^{\mathrm{a}}$ & -0.460 & 0.03 \\
\hline TM dust flux and CAR composite ${ }^{\mathrm{a}}$ & -0.691 & $<0.01$ & TM dust flux and CAR composite ${ }^{a}$ & 0.243 & 0.28 \\
\hline $\mathrm{MOH}$ dust and $\mathrm{MOH} \mathrm{CAR}^{\mathrm{b}}$ & 0.052 & 0.82 & $\mathrm{MOH}$ dust and $\mathrm{MOH} \mathrm{CAR}^{\mathrm{b}}$ & -0.538 & 0.01 \\
\hline TM dust and TM CAR ${ }^{\mathrm{b}}$ & 0.398 & 0.07 & TM dust and TM CAR ${ }^{\mathrm{b}}$ & 0.807 & $<0.01$ \\
\hline Charcoal and composite $\mathrm{CAR}^{\mathrm{c}}$ & $\mathrm{n} / \mathrm{a}$ & $\mathrm{n} / \mathrm{a}$ & Charcoal and composite $\mathrm{CAR}^{\mathrm{c}}$ & 0.948 & $<0.01$ \\
\hline \multicolumn{3}{|c|}{ 3950-3000 years BP } & \multicolumn{3}{|c|}{950 years BP to present } \\
\hline HYDE $\mathrm{p}$ & $\mathrm{n} / \mathrm{a}$ & $\mathrm{n} / \mathrm{a}$ & HYD & 0.571 & 0.01 \\
\hline HYDE cropland & $\mathrm{n} / \mathrm{a}$ & $\mathrm{n} / \mathrm{a}$ & HYDE cropland & 0.569 & 0.01 \\
\hline HYDE pasture & $\mathrm{n} / \mathrm{a}$ & $\mathrm{n} / \mathrm{a}$ & HYDE pasture & 0.465 & 0.03 \\
\hline Kaplan land use & 0.826 & $<0.01$ & Kaplan land use & 0.598 & $<0.01$ \\
\hline MOH dust flux and CAR composite ${ }^{\mathrm{a}}$ & -0.418 & 0.05 & $\mathrm{MOH}$ dust flux and CAR composite ${ }^{\mathrm{a}}$ & 0.497 & 0.02 \\
\hline TM dust flux and CAR composite ${ }^{a}$ & -0.216 & 0.33 & TM dust flux and CAR composite ${ }^{\mathrm{a}}$ & 0.120 & 0.60 \\
\hline $\mathrm{MOH}$ dust and $\mathrm{MOH} \mathrm{CAR}{ }^{\mathrm{b}}$ & 0.472 & 0.03 & $\mathrm{MOH}$ dust and $\mathrm{MOH} \mathrm{CAR}^{\mathrm{b}}$ & -0.142 & 0.53 \\
\hline TM dust and TM CAR ${ }^{b}$ & 0.684 & $<0.01$ & TM dust and TM CAR ${ }^{\mathrm{b}}$ & 0.717 & $<0.01$ \\
\hline Charcoal and composite $\mathrm{CAR}^{\mathrm{c}}$ & -0.733 & $<0.01$ & Charcoal and composite $\mathrm{CAR}^{\mathrm{c}}$ & 0.721 & $<0.01$ \\
\hline
\end{tabular}

a The correlation of the dust flux from the Mohos and Tăul Muced bogs with the composite CAR record.

$\mathrm{b}$ The correlation of the dust flux from the Mohos and Tăul Muced with individual CARs.

c The correlation of composite CAR with charcoal accumulation from Feurdean et al. (2020).

$\mathrm{n} / \mathrm{a}$ : not applicable due to lack of HYDE data.

the speed of peat decomposition. Recent peat has undergone less decomposition, resulting in higher levels of apparent carbon (Young et al., 2019).

\subsection{Comparison with other potential driving forces}

Some previous work also highlighted a range of other drivers behind peat accumulation rates, with mineral dust input listed as the primary driver of peat growth in a Swedish peatland (Kylander et al., 2018) and fluctuations in the supply of dust from the Loess Plateau in China found to be important in controlling local peat development (Pratte et al., 2020). We use the two existing peat records of Holocene dust deposition in the Romanian Carpathians to investigate this connec- tion (Longman et al., 2017b; Panait et al., 2019) in our study region (Fig. 5). A weak positive correlation between the TM dust flux and our composite CAR record may be representative of this linkage, but the $\mathrm{MOH}$ dust flux record appears to show little or no correlation with the composite CAR (Fig. 5, Table 4). This positive correlation is enhanced when the dust flux of Panait et al. (2019) is compared to the individual CAR values from TM (Fig. 5), with a highly significant positive correlation observed (Table 4). For MOH, a weaker but still statistically significant correlation is present (Table 4) between the dust flux of Longman et al. (2017b) and our CAR values (Fig. 5). These findings indicate that dust may be a local control on carbon accumulation but that each site must be treated individually, as dust may be local in source, with cer- 


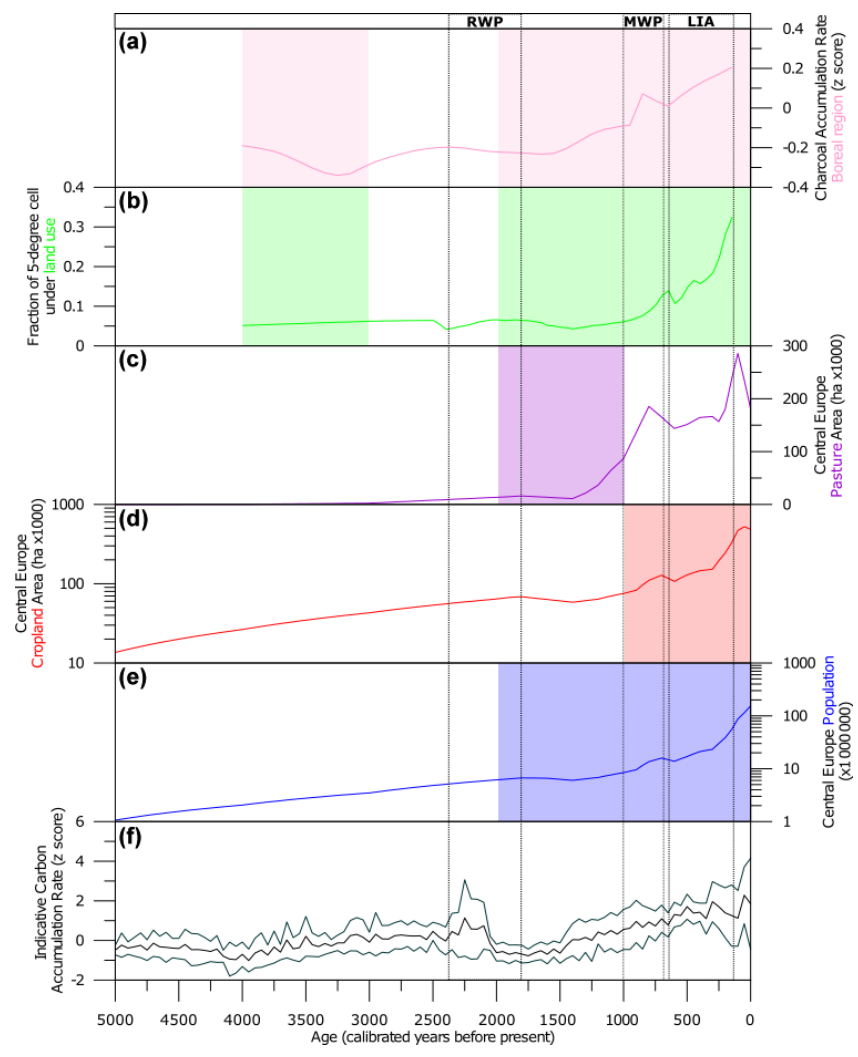

Figure 6. Comparison of the reconstructed carbon accumulation rate (CAR) for central-eastern Europe with four variables associated with land use and human impact. Panels (a)-(e) display the land use variables, with charcoal deposition in panel (a) (Feurdean et al., 2020), an estimate of total land use in panel (b) (from Kaplan et al., 2011), and three respective metrics of human impact (area of pasture, cropland, and total population) in panels (c)-(e) (Goldewijk et al., 2017). Panel (f) displays the CAR reconstruction from this study. Coloured rectangles indicate a correlation between the variable indicated by the colour and the CAR reconstruction, as in Fig. 4.

tain sources potentially much more nutrient-rich than others (Kylander et al., 2018; Longman et al., 2017b). In particular, dust from Saharan sources is likely to contain primarily quartz and carbonate clasts, which will not contain large quantities of phosphorous or nitrogen (Varga et al., 2016). Another factor in the control of CAR by dust deposition is the peat type, with ombrotrophic bogs considered very nutrient poor and, generally, phosphorous and nitrogen limited (Damman, 1986; Ratcliffe et al., 2020; Wang and Moore, 2014). This may explain the lack of strong correlation between our CAR composite and two regionally representative dust flux records (Table 4).

We showed that both dust input and variability in hydroclimate may have played a role in controlling CARs in the study region, but we hypothesize that human impact may have become the major controlling factor after 3000 years BP. To investigate this, we compare the CAR composite record with several land-use- and human-impact-related proxies from the HYDE dataset (Fig. 6). We focus on the last 2000 years of the record due to data availability, as only a single data point for every 1000 years is available from the HYDE dataset prior to 2000 years BP. However, these data are sufficient to indicate the strong positive correlations of population and land use with CARs in central-eastern Europe (Table 4). This is further supported by the comparison with land use as reconstructed by Kaplan et al. (2011) and by the strong positive correlation between the two datasets (Fig. 6, Table 4). To supplement this, we also carry out a comparison with a synthesis of eastern European biomass burning (Feurdean et al., 2020). In the studied period, it appears that biomass burning was primarily controlled by human-driven tree felling and burning; thus, it may be used to estimate the levels of land exploitation (Feurdean et al., 2020). There are strong positive correlations between CARs and biomass burning in the last 2000 years (Fig. 6, Table 4). This finding suggests that biomass burning and associated forest removal has a positive impact on central and eastern European peatland CARs. As described earlier, increased human impact (e.g. logging, use of fire) leads to reduced forest cover (Feurdean et al., 2020) and increased weathering (Longman et al., 2017a). Greater biomass burning suggests greater deforestation as well as the possibility of more soil entrainment. This links to our assertion of a dust-related control, as local dust sources may be linked to local deforestation and periodic topsoil exposure (Longman et al., 2017b; Panait et al., 2019). However, it has been proposed that the changing dust flux is solely related to climatic controls (e.g. Marx et al., 2009); therefore, in order to further investigate a potential controlling impact of local dust and erosion, we compare the model data to the reconstruction of dust flux from Mohos (Table S3). This exercise clearly indicates the covariance of dust and climatic forcing factors (especially precipitation) when considering the whole record. However, for the periods in which we infer local erosion and dust supply stimulating peat growth, there are either very weak or not statistically significant correlations between climate and dust (Table S3). Such a finding indicates the disconnect between climate and dust flux over the last 2000 years and supports our assertion of local dust drivers in this period.

This data comparison exercise clearly indicates the complexity of factors controlling mountain peat CARs as well as the fact that prediction of the behaviour of the peatland carbon sink is a challenge. Considering climate indices, it appears that there is a relationship between mean temperature and CAR and, potentially, between mean temperature and the availability of moisture during the growing season (Table 4). In Romania, average temperatures are predicted to increase in the coming decades, with concurrent increases in summer and spring precipitation as well as decreases in winter (Ministry of Environment and Climate Change, 2013). As such, it is likely that these conditions will lead to increased peat growth and enhanced CARs. However, as we have shown, 
the primary control on CARs for much of the last 4000 years has been the combination of human impact, local soil erosion, and the periodic deposition of dust that has undergone long-range transport. Changes in erosion are reliant upon a range of local factors, and dust fluxes are often controlled by distal droughts; thus, it is not possible to predict how erosion rates will change in the future for each individual bog location. Our work clearly demonstrates that CARs are not purely controlled by climate and that predictions of the future size of the global peatland carbon sink must be adjusted to take local factors relating to human activities into account (Gallego-Sala et al., 2018).

\section{Conclusions}

Using nine peatbog records from the Carpathians, we compiled a detailed record of changing carbon accumulation rates (CARs) through the Holocene. Our CAR data indicate that bogs located in the Carpathian Mountains are potentially very efficient carbon sinks, with long-term apparent CAR values that are amongst the highest in the published literature and that are comparable to high mountain bogs in South America. As a result, the peatland carbon sink in the Carpathians and throughout central-eastern Europe may be large, despite the small area of peatland coverage. Our work suggests that mountain bogs should be considered in future estimates of the peatland carbon sink and that further studies are needed to refine estimates of carbon accumulation in such environments.

From our reconstructions, CARs varied throughout the Holocene, with high rates recorded in the early Holocene (10 000-7000 years BP), followed by a slow decline, culminating in CAR nadir around 4000 years BP. These results may be linked to the warm climate of the early Holocene stimulating peat growth before gradual cooling and the possible impact of the cold $4.2 \mathrm{ka}$ event. This is supported by a comparison to palaeoclimatic model data from the period from 5000 to 4000 years BP, with strong correlations between temperature and CAR. After 3000 years BP, there is a clear shift in the controls on peat accumulation, with no apparent correlations between CARs and temperatures. Instead, we suggest that late-Holocene CARs are controlled by a combination of human activity and dust input. A clear peak in CARs occurs at the same time as the Roman Warm Period and the rise of the Roman Empire, which would have introduced greater land use and resulted in increased erosion and mineral input into bogs, supplying nutrients and resulting in increased CARs. Alongside this, increases in dust flux correlate well with individual CAR reconstructions, indicating that changing dust sources and levels of dust transport to the region may have led to local CAR responses. In the most recent part of the records, sharp rises in CARs are reconstructed, potentially indicating the impact that warmer tem- peratures due to greenhouse gas emissions are having on peat growth.

Our work indicates the potentially large carbon sink represented by mountainous peatlands in Romania and Serbia. To better constrain their importance in the regional carbon cycle, more work is necessary to investigate other carbon sinks in these countries, such as lake sediments, forest soils, and lowland peatlands. Work in these environments should help to better understand the size of the current carbon sink and how the carbon sink has varied in the past. This would help to determine exactly how important mountain bogs are in the regional carbon balance, and, when combined with management and monitoring exercises, may help to mitigate the worst of the impacts of anthropogenic climate change.

Data availability. All data generated in the course of this study are available from the following Figshare links: https://doi.org/10.6084/m9.figshare.16930987.v1 (Longman, 2021b) and https://doi.org/10.6084/m9.figshare.16930867.v1 (Longman, 2021a).

Supplement. The supplement related to this article is available online at: https://doi.org/10.5194/cp-17-2633-2021-supplement.

Author contributions. JL, DV, AH, VE, and WF were responsible for conceptualizing the study. JL, DV, and WF developed the methodology. JL, DV, VE, AH, WF, and DP undertook the formal analysis. JL, DV, AH, WF, TS, DP, and RB carried out the investigation. DV, VE, TS, DP, and RB were responsible for resource acquisition. JL, DV, and WF wrote the original draft of the paper, and JL, DV, AH, VE, WF, and TS reviewed and edited it. JL and AH created the figures. DV was responsible for funding acquisition.

Competing interests. The contact author has declared that neither they nor their co-authors have any competing interests.

Disclaimer. Publisher's note: Copernicus Publications remains neutral with regard to jurisdictional claims in published maps and institutional affiliations.

Acknowledgements. The authors are indebted to Slobodan B. Marković, Nemanja Tomić, Igor Obreht, and Szabolcs Kelemen for fieldwork support. The authors acknowledge the financial support from the Romanian Ministry of Education and Research. We are grateful for the insightful comments from Joshua Ratcliffe and Nicole Sanderson, who helped improve the paper.

Financial support. This research has been supported by the Romanian Ministry of Education and Research, CNCS - UEFISCDI (grant no. 85 PN-III-P4-ID-PCE-2020-0914). 
Review statement. This paper was edited by Julie Loisel and reviewed by Joshua Ratcliffe and Nicole Sanderson.

\section{References}

Asada, T., Warner, B. G., and Banner, A.: Growth of Mosses in Relation to Climate Factors in a Hypermaritime Coastal Peatland in British Columbia, Canada, Bryologist, 106, 516-527, https://doi.org/10.1639/00072745(2003)106[516:GOMIRT]2.0.CO;2, 2003.

Berger, A. and Loutre, M. F.: Insolation values for the climate of the last 10 million years, Quaternary Sci. Rev., 10, 297-317, https://doi.org/10.1016/0277-3791(91)90033-Q, 1991.

Bini, M., Zanchetta, G., Perşoiu, A., Cartier, R., Català, A., Cacho, I., Dean, J. R., Di Rita, F., Drysdale, R. N., Finnè, M., Isola, I., Jalali, B., Lirer, F., Magri, D., Masi, A., Marks, L., Mercuri, A. M., Peyron, O., Sadori, L., Sicre, M.-A., Welc, F., Zielhofer, C., and Brisset, E.: The $4.2 \mathrm{kaBP}$ Event in the Mediterranean region: an overview, Clim. Past, 15, 555-577, https://doi.org/10.5194/cp-15-555-2019, 2019.

Blaauw, M. and Christen, J. A.: Flexible paleoclimate age-depth models using an autoregressive gamma process, Bayesian Anal., 6, 457-474, 2011.

Breeuwer, A., Heijmans, M. M. P. D., Robroek, B. J. M., and Berendse, F.: The effect of temperature on growth and competition between Sphagnum species, Oecologia, 156, 155-167, https://doi.org/10.1007/s00442-008-0963-8, 2008.

Buczkó, K., Magyari, E. K., Braun, M., and Bálint, M.: Diatominferred lateglacial and Holocene climatic variability in the South Carpathian Mountains (Romania), Quatern. Int., 293, 123-135, https://doi.org/10.1016/j.quaint.2012.04.042, 2013.

Buntgen, U., Tegel, W., Nicolussi, K., McCormick, M., Frank, D., Trouet, V., Kaplan, J. O., Herzig, F., Heussner, K.-U., Wanner, H., Luterbacher, J., and Esper, J.: 2500 Years of European Climate Variability and Human Susceptibility, Science, 331, 578582, https://doi.org/10.1126/science.1197175, 2011.

Charman, D. J., Barber, K. E., Blaauw, M., Langdon, P. G., Mauquoy, D., Daley, T. J., Hughes, P. D. M., and Karofeld, E.: Climate drivers for peatland palaeoclimate records, Quaternary Sci. Rev., 28, 1811-1819, https://doi.org/10.1016/j.quascirev.2009.05.013, 2009.

Charman, D. J., Beilman, D. W., Blaauw, M., Booth, R. K., Brewer, S., Chambers, F. M., Christen, J. A., Gallego-Sala, A., Harrison, S. P., Hughes, P. D. M., Jackson, S. T., Korhola, A., Mauquoy, D., Mitchell, F. J. G., Prentice, I. C., van der Linden, M., De Vleeschouwer, F., Yu, Z. C., Alm, J., Bauer, I. E., Corish, Y. M. C., Garneau, M., Hohl, V., Huang, Y., Karofeld, E., Le Roux, G., Loisel, J., Moschen, R., Nichols, J. E., Nieminen, T. M., MacDonald, G. M., Phadtare, N. R., Rausch, N., Sillasoo, Ü., Swindles, G. T., Tuittila, E.-S., Ukonmaanaho, L., Väliranta, M., van Bellen, S., van Geel, B., Vitt, D. H., and Zhao, Y.: Climate-related changes in peatland carbon accumulation during the last millennium, Biogeosciences, 10, 929-944, https://doi.org/10.5194/bg-10-929-2013, 2013.

Charman, D. J., Amesbury, M. J., Hinchliffe, W., Hughes, P. D. M., Mallon, G., Blake, W. H., Daley, T. J., GallegoSala, A. V., and Mauquoy, D.: Drivers of Holocene peatland carbon accumulation across a climate gradient in north- eastern North America, Quaternary Sci. Rev., 121, 110-119, https://doi.org/10.1016/j.quascirev.2015.05.012, 2015.

Chen, H., Yang, G., Peng, C., Zhang, Y., Zhu, D., Zhu, Q., Hu, J., Wang, M., Zhan, W., Zhu, E., Bai, Z., Li, W., Wu, N., Wang, Y., Gao, Y., Tian, J., Kang, X., Zhao, X., and Wu, J.: The carbon stock of alpine peatlands on the Qinghai-Tibetan Plateau during the Holocene and their future fate, Quaternary Sci. Rev., 95, 151158, https://doi.org/10.1016/j.quascirev.2014.05.003, 2014.

Chevalier, M., Davis, B. A. S., Heiri, O., Seppä, H., Chase, B. M., Gajewski, K., Lacourse, T., Telford, R. J., Finsinger, W., Guiot, J., Kühl, N., Maezumi, S. Y., Tipton, J. R., Carter, V. A., Brussel, T., Phelps, L. N., Dawson, A., Zanon, M., Vallé, F., Nolan, C., Mauri, A., de Vernal, A., Izumi, K., Holmström, L., Marsicek, J., Goring, S., Sommer, P. S., Chaput, M., and Kupriyanov, D.: Pollen-based climate reconstruction techniques for late Quaternary studies, Earth-Sci. Rev., 210, 103384, https://doi.org/10.1016/j.earscirev.2020.103384, 2020.

Chimner, R. A. and Karberg, J. M.: Long-term carbon accumulation in two tropical mountain peatlands, Andes Mountains, Ecuador, Mires Peat, 3, 1-10, online, available at: http://www. mires-and-peat.net/ (last access: 19 March 2021), 2008.

Cleary, D. M., Onac, B. P., Tanţău, I., Forray, F. L., Wynn, J. G., Ionita, M., and Tămaş, T.: A guano-derived $\delta^{13} \mathrm{C}$ and $\delta^{15} \mathrm{~N}$ record of climate since the Medieval Warm Period in north-west Romania, J. Quaternary Sci., 33, 677-688, https://doi.org/10.1002/jqs.3044, 2018.

Clymo, R.S., Turunen, J., and Tolonen, K.: Carbon accumulation in peatland, Oikos, 368-388, 1998.

Constantin, S., Bojar, A.-V., Lauritzen, S.-E., and Lundberg, J.: Holocene and Late Pleistocene climate in the sub-Mediterranean continental environment: A speleothem record from Poleva Cave (Southern Carpathians, Romania), Palaeogeogr. Palaeocl., 243, 322-338, https://doi.org/10.1016/j.palaeo.2006.08.001, 2007.

Crippa, M., Guizzardi, D., Solazzon, E., Muntean, M., Schaaf, E., Monforti-Ferrario, F., Banja, M., Olivier, J. G. J., Grassi, G., Rossi, S., and Vignati, E.: GHG emissions of all world countries - 2021 Report, Office of the European Union, Luxembourg, 2021.

Cristea, G., Cuna, S. M., Farcas, S., Tantau, I., Dordai, E., and Magdas, D. A.: Carbon isotope composition as indicator for climatic changes during the middle and late Holocene in a peat bog from Maramures Mountains (Romania), Holocene, 24, 15-23, https://doi.org/10.1177/0959683613512166, 2013.

Damman, A. W. H.: Hydrology, development, and biogeochemistry of ombrogenous peat bogs with special reference to nutrient relocation in a western Newfoundland bog., Can. J. Botany, 64, 384-394, https://doi.org/10.1139/b86-055, 1986.

Dargie, G. C., Lewis, S. L., Lawson, I. T., Mitchard, E. T. A., Page, S. E., Bocko, Y. E., and Ifo, S. A.: Age, extent and carbon storage of the central Congo Basin peatland complex, Nature, 542, 8690, https://doi.org/10.1038/nature21048, 2017.

Davis, B. A. S., Brewer, S., Stevenson, A. C., and Guiot, J.: The temperature of Europe during the Holocene reconstructed from pollen data, Quaternary Sci. Rev., 22, 1701-1716, https://doi.org/10.1016/S0277-3791(03)00173-2, 2003.

Diaconu, A. C., Tóth, M., Lamentowicz, M., Heiri, O., Kuske, E., Tanţău, I., Panait, A. M., Braun, M., and Feurdean, A.: How warm? How wet? Hydroclimate reconstruction of the past 7500 years in northern 
Carpathians, Romania, Palaeogeogr. Palaeocl., 482, 1-12, https://doi.org/10.1016/j.palaeo.2017.05.007, 2017.

Drăguşin, V., Staubwasser, M., Hoffmann, D. L., Ersek, V., Onac, B. P., and Veres, D.: Constraining Holocene hydrological changes in the Carpathian-Balkan region using speleothem $\delta^{18} \mathrm{O}$ and pollen-based temperature reconstructions, Clim. Past, 10, 13631380, https://doi.org/10.5194/cp-10-1363-2014, 2014.

Feurdean, A., Klotz, S., Mosbrugger, V., and Wohlfarth, B.: Pollenbased quantitative reconstructions of Holocene climate variability in NW Romania, Palaeogeogr. Palaeocl., 260, 494-504, https://doi.org/10.1016/j.palaeo.2007.12.014, 2008.

Feurdean, A., Tanţâu, I., and Fârcaş, S.: Holocene variability in the range distribution and abundance of Pinus, Picea abies, and Quercus in Romania; implications for their current status, Quaternary Sci. Rev., 30, 3060-3075, https://doi.org/10.1016/j.quascirev.2011.07.005, 2011.

Feurdean, A., Galka, M., Kuske, E., Tantau, I., Lamentowicz, M., Florescu, G., Liakka, J., Hutchinson, S. M., Mulch, A., and Hickler, T.: Last Millennium hydro-climate variability in CentralEastern Europe (Northern Carpathians, Romania), Holocene, 25, 1179-1192, https://doi.org/10.1177/0959683615580197, 2015.

Feurdean, A., Vannière, B., Finsinger, W., Warren, D., Connor, S. C., Forrest, M., Liakka, J., Panait, A., Werner, C., Andrič, M., Bobek, P., Carter, V. A., Davis, B., Diaconu, A.-C., Dietze, E., Feeser, I., Florescu, G., Gałka, M., Giesecke, T., Jahns, S., Jamrichová, E., Kajukało, K., Kaplan, J., Karpińska-Kołaczek, M., Kołaczek, P., Kuneš, P., Kupriyanov, D., Lamentowicz, M., Lemmen, C., Magyari, E. K., Marcisz, K., Marinova, E., Niamir, A., Novenko, E., Obremska, M., Pȩdziszewska, A., Pfeiffer, M., Poska, A., Rösch, M., Słowiński, M., Stančikaitè, M., Szal, M., Święta-Musznicka, J., Tanţău, I., Theuerkauf, M., Tonkov, S., Valkó, O., Vassiljev, J., Veski, S., Vincze, I., Wacnik, A., Wiethold, J., and Hickler, T.: Fire hazard modulation by long-term dynamics in land cover and dominant forest type in eastern and central Europe, Biogeosciences, 17, 1213-1230, https://doi.org/10.5194/bg-17-1213-2020, 2020.

Finsinger, W., Colombaroli, D., De Beaulieu, J.-L., Valsecchi, V., Vannière, B., Vescovi, E., Chapron, E., Lotter, A. F., Magny, M., and Tinner, W.: Early to mid-Holocene climate change at Lago dell'Accesa (central Italy): climate signal or anthropogenic bias?, J. Quaternary Sci., 25, 1239-1247, https://doi.org/10.1002/jqs.1402, 2010.

Finsinger, W., Morales-Molino, C., Gałka, M., Valsecchi, V., Bojovic, S., and Tinner, W.: Holocene vegetation and fire dynamics at Crveni Potok, a small mire in the Dinaric Alps (Tara National Park, Serbia), Quaternary Sci. Rev., 167, 63-77, https://doi.org/10.1016/j.quascirev.2017.04.032, 2017.

Fordham, D. A., Saltré, F., Haythorne, S., Wigley, T. M. L., OttoBliesner, B. L., Chan, K. C., and Brook, B. W.: PaleoView: a tool for generating continuous climate projections spanning the last 21000 years at regional and global scales, Ecography, 40, 1348-1358, https://doi.org/10.1111/ecog.03031, 2017.

Forray, F. L., Onac, B. P., Tanţău, I., Wynn, J. G., Tămaş, T., Coroiu, I., and Giurgiu, A. M.: A Late Holocene environmental history of a bat guano deposit from Romania: an isotopic, pollen and microcharcoal study, Quaternary Sci. Rev., 127, 141-154, https://doi.org/10.1016/j.quascirev.2015.05.022, 2015.

Gałka, M., Tanţău, I., Ersek, V., and Feurdean, A.: A 9000 year record of cyclic vegetation changes identified in a mon- tane peatland deposit located in the Eastern Carpathians (Central-Eastern Europe): Autogenic succession or regional climatic influences?, Palaeogeogr. Palaeocl., 449, 52-61, https://doi.org/10.1016/j.palaeo.2016.02.007, 2016.

Gallagher, K., Bodin, T., Sambridge, M., Weiss, D., Kylander, M., and Large, D.: Inference of abrupt changes in noisy geochemical records using transdimensional changepoint models, Earth Planet. Sc. Lett., 311, 182-194, 2011.

Gallego-Sala, A. V., Charman, D. J., Brewer, S., Page, S. E., Prentice, I. C., Friedlingstein, P., Moreton, S., Amesbury, M. J., Beilman, D. W., Björck, S., Blyakharchuk, T., Bochicchio, C., Booth, R. K., Bunbury, J., Camill, P., Carless, D., Chimner, R. A., Clifford, M., Cressey, E., Courtney-Mustaphi, C., De Vleeschouwer, F., de Jong, R., Fialkiewicz-Koziel, B., Finkelstein, S. A., Garneau, M., Githumbi, E., Hribjlan, J., Holmquist, J., Hughes, P. D. M., Jones, C., Jones, M. C., Karofeld, E., Klein, E. S., Kokfelt, U., Korhola, A., Lacourse, T., Le Roux, G., Lamentowicz, M., Large, D., Lavoie, M., Loisel, J., Mackay, H., MacDonald, G. M., Makila, M., Magnan, G., Marchant, R., Marcisz, K., Martínez Cortizas, A., Massa, C., Mathijssen, P., Mauquoy, D., Mighall, T. Mitchell, F. J. G., Moss, P., Nichols, J., Oksanen, P. O., Orme, L., Packalen, M. S., Robinson, S., Roland, T. P., Sanderson, N. K., Sannel, A. B. K., Silva-Sánchez, N., Steinberg, N., Swindles, G. T., Turner, T. E., Uglow, J., Väliranta, M., van Bellen, S., van der Linden, M., van Geel, B., Wang, G., Yu, Z., Zaragoza-Castells, J., and Zhao, Y.: Latitudinal limits to the predicted increase of the peatland carbon sink with warming, Nat. Clim. Change, 8 , 907-913, https://doi.org/10.1038/s41558-018-0271-1, 2018.

Garnett, M. H., Ineson, P., and Stevenson, A. C.: Effects of burning and grazing on carbon sequestration in a Pennine blanket bog, UK, Holocene, 10, 729-736, https://doi.org/10.1191/09596830094971, 2000.

Giosan, L., Coolen, M. J. L., Kaplan, J. O., Constantinescu, S., Filip, F., Filipova-Marinova, M., Kettner, A. J., and Thom, N.: Early Anthropogenic Transformation of the Danube-Black Sea System, Sci. Rep., 2, 1-6, https://doi.org/10.1038/srep00582, 2012.

Gunnarsson, U.: Global patterns of Sphagnum productivity, J. Bryol., 27, 269-279, https://doi.org/10.1179/174328205X70029, 2005.

Haliuc, A., Veres, D., Hubay, K., Brauer, A., Hutchinson, S. M., Begy, R., Hubay, K., Hutchinson, S. M., Begy, R., and Braun, M.: Palaeohydrological changes over mid and late Holocene in the Carpathian area, central-eastern Europe, Global Planet. Change, 152, 1-43, https://doi.org/10.1016/j.gloplacha.2017.02.010, 2017.

Hapsari, K. A., Biagioni, S., Jennerjahn, T. C., Reimer, P. M., Saad, A., Achnopha, Y., Sabiham, S., and Behling, H.: Environmental dynamics and carbon accumulation rate of a tropical peatland in Central Sumatra, Indonesia, Quaternary Sci. Rev., 169, 173-187, https://doi.org/10.1016/j.quascirev.2017.05.026, 2017.

Haliuc, A., Buczkó, K., Hutchinson, S. M., Ács, É., Magyari, E. K., Korponai, J., Begy, R. C., Vasilache, D., Zak, M., and Veres, D.: Climate and land-use as the main drivers of recent environmental change in a mid-altitude mountain lake, Romanian Carpathians, PloS one, 15, e0239209, https://doi.org/10.1371/journal.pone.0248253, 2020.

Heiri, O., Lotter, A. F., and Lemcke, G.: Loss on ignition as a method for estimating organic and carbonate content in sedi- 
ments: reproducibility and comparability of results, J. Paleolimnol., 25, 101-110, 2001.

Holden, A. S., Sullivan, A. P., Munchak, L. a., Kreidenweis, S. M., Schichtel, B. a., Malm, W. C., and Collett, J. L.: Determining contributions of biomass burning and other sources to fine particle contemporary carbon in the western United States, Atmos. Environ., 45, 1986-1993, https://doi.org/10.1016/j.atmosenv.2011.01.021, 2011.

Holmquist, J. R., Finkelstein, S. A., Garneau, M., Massa, C., Yu, Z., and MacDonald, G. M.: A comparison of radiocarbon ages derived from bulk peat and selected plant macrofossils in basal peat cores from circum-arctic peatlands, Quat. Geochronol., 31, 53-61, https://doi.org/10.1016/j.quageo.2015.10.003, 2016.

Howard, A. J., Macklin, M. G., Bailey, D. W., Mills, S., and Andreescu, R.: Late-glacial and Holocene river development in the Teleorman Valley on the southern Romanian Plain, J. Quaternary Sci., 19, 271-280, https://doi.org/10.1002/jqs.805, 2004.

Hugelius, G., Loisel, J., Chadburn, S., Jackson, R. B., Jones, M., MacDonald, G., Marushchak, M., Olefeldt, D., Packalen, M., Siewert, M. B., Treat, C., Turetsky, M., Voigt, C., and Yu, Z.: Large stocks of peatland carbon and nitrogen are vulnerable to permafrost thaw, P. Natl. Acad. Sci. USA, 117, 20438-20446, https://doi.org/10.1073/pnas.1916387117, 2020.

Hughes, J. D. and Thirgood, J. V.: Deforestation, Erosion, and Forest Management in Ancient Greece and Rome, Journal of Forest History, 26, 60-75, https://doi.org/10.2307/4004530, 1982.

Hughes, P. D. M., Mallon, G., Brown, A., Essex, H. J., Stanford, J. D., and Hotes, S.: The impact of high tephra loading on late-Holocene carbon accumulation and vegetation succession in peatland communities, Quaternary Sci. Rev., 67, 160-175, https://doi.org/10.1016/j.quascirev.2013.01.015, 2013.

Jassey, V. E. J. and Signarbieux, C.: Effects of climate warming on Sphagnum photosynthesis in peatlands depend on peat moisture and species-specific anatomical traits, Glob. Change Biol., 25, 3859-3870, https://doi.org/10.1111/gcb.14788, 2019.

Jones, M. C. and Yu, Z.: Rapid deglacial and early Holocene expansion of peatlands in Alaska, P. Natl. Acad. Sci. USA, 107, 7347-7352, https://doi.org/10.1073/pnas.0911387107, 2010.

Kaplan, J. O., Krumhardt, K. M., Ellis, E. C., Ruddiman, W. F., Lemmen, C., and Goldewijk, K. K.: Holocene carbon emissions as a result of anthropogenic land cover change, Holocene, 21, 775-791, https://doi.org/10.1177/0959683610386983, 2011.

Klein Goldewijk, K., Beusen, A., Doelman, J., and Stehfest, E.: Anthropogenic land use estimates for the Holocene - HYDE 3.2, Earth Syst. Sci. Data, 9, 927-953, https://doi.org/10.5194/essd9-927-2017, 2017.

Kou, J., Wang, T., Yu, F., Sun, Y., Feng, C., and Shao, $\mathrm{X}$.: The moss genus Didymodon as an indicator of climate change on the Tibetan Plateau, Ecol. Indic., 113, 106204, https://doi.org/10.1016/j.ecolind.2020.106204, 2020.

Kuhry, P.: The Role of Fire in the Development of SphagnumDominated Peatlands in Western Boreal Canada, J. Ecol., 82, 899, https://doi.org/10.2307/2261453, 1994.

Kurnianto, S., Warren, M., Talbot, J., Kauffman, B., Murdiyarso, D., and Frolking, S.: Carbon accumulation of tropical peatlands over millennia: a modeling approach, Glob. Change Biol., 21, 431-444, https://doi.org/10.1111/gcb.12672, 2015.

Kylander, M. E., Martínez-Cortizas, A., Bindler, R., Kaal, J., Sjöström, J. K., Hansson, S. V., Silva-Sánchez, N., Greenwood,
S. L., Gallagher, K., Rydberg, J., Mörth, C. M., and Rauch, S. Mineral dust as a driver of carbon accumulation in northern latitudes, Sci. Rep., 8, 1-10, https://doi.org/10.1038/s41598-01825162-9, 2018.

Leifeld, J., Wüst-Galley, C., and Page, S.: Intact and managed peatland soils as a source and sink of GHGs from 1850 to 2100 , Nat. Clim. Change, 9, 945-947, https://doi.org/10.1038/s41558-0190615-5, 2019.

Loisel, J., Gallego-Sala, A. V., and Yu, Z.: Global-scale pattern of peatland Sphagnum growth driven by photosynthetically active radiation and growing season length, Biogeosciences, 9, 2737 2746, https://doi.org/10.5194/bg-9-2737-2012, 2012.

Loisel, J., Yu, Z., Beilman, D. W., Camill, P., Alm, J., Amesbury, M. J., Anderson, D., Andersson, S., Bochicchio, C., Barber, K., Belyea, L. R., Bunbury, J., Chambers, F. M., Charman, D. J., De Vleeschouwer, F., Fiałkiewicz-Kozieł, B., Finkelstein, S. A., Gał ka, M., Garneau, M., Hammarlund, D., Hinchcliffe, W., Holmquist, J., Hughes, P., Jones, M. C., Klein, E. S., Kokfelt, U., Korhola, A., Kuhry, P., Lamarre, A., Lamentowicz, M., Large, D., Lavoie, M., MacDonald, G., Magnan, G., Mäkilä, M., Mallon, G., Mathijssen, P., Mauquoy, D., McCarroll, J., Moore, T. R., Nichols, J., O'Reilly, B., Oksanen, P., Packalen, M., Peteet, D., Richard, P. J., Robinson, S., Ronkainen, T., Rundgren, M., Sannel, A. B. K., Tarnocai, C., Thom, T., Tuittila, E.-S., Turetsky, M., Väliranta, M., van der Linden, M., van Geel, B., van Bellen, S., Vitt, D., Zhao, Y., and Zhou, W.: A database and synthesis of northern peatland soil properties and Holocene carbon and nitrogen accumulation, Holocene, 24, 1028-1042, https://doi.org/10.1177/0959683614538073, 2014.

Loisel, J., Gallego-Sala, A. V., Amesbury, M. J., Magnan, G., Anshari, G., Beilman, D. W., Benavides, J. C., Blewett, J., Camill, P., Charman, D. J., Chawchai, S., Hedgpeth, A., Kleinen, T., Korhola, A., Large, D., Mansilla, C. A., Müller, J., van Bellen, S., West, J. B., Yu, Z., Bubier, J. L., Garneau, M., Moore, T., Sannel, A. B. K., Page, S., Väliranta, M., Bechtold, M., Brovkin, V., Cole, L. E. S., Chanton, J. P., Christensen, T. R., Davies, M. A., De Vleeschouwer, F., Finkelstein, S. A., Frolking, S., Gałka, M., Gandois, L., Girkin, N., Harris, L. I., Heinemeyer, A., Hoyt, A. M., Jones, M. C., Joos, F., Juutinen, S., Kaiser, K., Lacourse, T., Lamentowicz, M., Larmola, T., Leifeld, J., Lohila, A., Milner, A. M., Minkkinen, K., Moss, P., Naafs, B. D. A., Nichols, J., O’Donnell, J., Payne, R., Philben, M., Piilo, S., Quillet, A., Ratnayake, A. S., Roland, T. P., Sjögersten, S., Sonnentag, O., Swindles, G. T., Swinnen, W., Talbot, J., Treat, C., Valach, A. C., and $\mathrm{Wu}, \mathrm{J}$. : Expert assessment of future vulnerability of the global peatland carbon sink, Nat. Clim. Change, 11, 70-77, https://doi.org/10.1038/s41558-020-00944-0, 2021.

Longman, J.: Carbon Accumulation rates from range of bogs in Romania and Serbia, figshare [data set], https://doi.org/10.6084/m9.figshare.16930867.v1, 2021a.

Longman, J.: Carbon Accumulation Rate synthesis from CE Europe, figshare [data set], https://doi.org/10.6084/m9.figshare.16930987.v1, 2021b.

Longman, J., Ersek, V., Veres, D., and Salzmann, U.: Detrital events and hydroclimate variability in the Romanian Carpathians during the Mid-to-Late Holocene, Quaternary Sci. Rev., 167, 78-95, https://doi.org/10.1016/j.quascirev.2017.04.029, 2017a.

Longman, J., Veres, D., Ersek, V., Salzmann, U., Hubay, K., Bormann, M., Wennrich, V., and Schäbitz, F.: Periodic input of dust 
over the Eastern Carpathians during the Holocene linked with Saharan desertification and human impact, Clim. Past, 13, 897917, https://doi.org/10.5194/cp-13-897-2017, 2017b.

Longman, J., Veres, D., Finsinger, W., and Ersek, V.: Exceptionally high levels of lead pollution in the Balkans from the Early Bronze Age to the Industrial Revolution., P. Natl. Acad. Sci. USA, 115, E5661-E5668, https://doi.org/10.1073/pnas.1721546115, 2018.

Longman, J., Veres, D., Ersek, V., Haliuc, A., and Wennrich, V.: Runoff events and related rainfall variability in the Southern Carpathians during the last 2000 years, Sci. Rep., 9, 5334, https://doi.org/10.1038/s41598-019-41855-1, 2019.

Magnan, G. and Garneau, M.: Climatic and autogenic control on Holocene carbon sequestration in ombrotrophic peatlands of maritime Quebec, eastern Canada, The Holocene, 24, 10541062, https://doi.org/10.1177/0959683614540727, 2014.

Magyari, E., Buczkó, K., Jakab, G., Braun, M., Pál, Z., Karátson, D., and Pap, I.: Palaeolimnology of the last crater lake in the Eastern Carpathian Mountains: a multiproxy study of Holocene hydrological changes, Hydrobiologia, 631, 29-63, 2009.

Magyari, E. K., Demény, A., Buczkó, K., Kern, Z., Vennemann, T., Fórizs, I., Vincze, I., Braun, M., Kovács, J. I., Udvardi, B., and Veres, D.: A 13,600 year diatom oxygen isotope record from the South Carpathians (Romania): Reflection of winter conditions and possible links with North Atlantic circulation changes, Quatern. Int., 293, 136-149, https://doi.org/10.1016/j.quaint.2012.05.042, 2013.

Marlon, J. R., Kelly, R., Daniau, A.-L., Vannière, B., Power, M. J., Bartlein, P., Higuera, P., Blarquez, O., Brewer, S., Brücher, T., Feurdean, A., Romera, G. G., Iglesias, V., Maezumi, S. Y., Magi, B., Courtney Mustaphi, C. J., and Zhihai, T.: Reconstructions of biomass burning from sediment-charcoal records to improve data-model comparisons, Biogeosciences, 13, 3225-3244, https://doi.org/10.5194/bg-13-3225-2016, 2016.

Marx, S. K., McGowan, H. A., and Kamber, B. S.: Long-range dust transport from eastern Australia: A proxy for Holocene aridity and ENSO-type climate variability, Earth Planet. Sc. Lett., 282, 167-177, https://doi.org/10.1016/j.epsl.2009.03.013, 2009.

Mauri, A., Davis, B. A. S., Collins, P. M., and Kaplan, J. O.: The climate of Europe during the Holocene: a gridded pollen-based reconstruction and its multiproxy evaluation, Quaternary Sci. Rev., 112, 109-127, https://doi.org/10.1016/j.quascirev.2015.01.013, 2015.

Ministry of Environmentand Climate Change: Romania's Sixth National Communication on Climate Change and First Biennial Report, Ministry of Environment and Climate Change, Bucharest, Romania, 2013.

Nieveen, J. P., Campbell, D. I., Schipper, L. A., and Blair, I. J.: Carbon exchange of grazed pasture on a drained peat soil, Glob. Change Biol., 11, 607-618, https://doi.org/10.1111/j.13652486.2005.00929.x, 2005.

O'Donnell, M. S. and Ignizio, D. A.: Bioclimatic Predictors for Supporting Ecological Applications in the Conterminous United States, Reston, online, available at: https://pubs.usgs.gov/ds/691/ (last access: 22 March 2021), 2012.

Obreht, I., Zeeden, C., Hambach, U., Veres, D., Marković, S. b., Bösken, J., Svirčev, Z., Bačević, N., Gavrilov, M. B., and Lehmkuhl, F.: Tracing the influence of Mediterranean climate on Southeastern Europe during the past 350,000 years, Sci. Rep., 6, 36334, https://doi.org/10.1038/srep36334, 2016.
Oke, T. A. and Hager, H. A.: Assessing environmental attributes and effects of climate change on Sphagnum peatland distributions in North America using single- and multi-species models, edited by: Bussmann, R., PLoS One, 12, e0175978, https://doi.org/10.1371/journal.pone.0175978, 2017.

Olofsson, P., Woodcock, C. E., Baccini, A., Houghton, R. A., Ozdogan, M., Gancz, V., Blujdea, V., Torchinava, P., Tufekcioglu, A., and Baskent, E. Z.: The Effects of Land Use Change on Terrestrial Carbon Dynamics in the Black Sea Region, in Regional Aspects of Climate-Terrestrial-Hydrologic Interactions in Nonboreal Eastern Europe, edited by: Groisman, P. and Ivanov, S., 175-182, Springer Netherlands, Dordrecht, 2009.

Olsen, J., Anderson, N. J., and Knudsen, M. F.: Variability of the North Atlantic Oscillation over the past 5,200 years, Nat. Geosci., 5, 1-14, https://doi.org/10.1038/ngeo1589, 2012.

Onac, B. P., Constantin, S., Lundberg, J., and Lauritzen, S. E.: Isotopic climate record in a Holocene stalagmite from Ursilor Cave (Romania), J. Quaternary Sci., 17, 319-327, https://doi.org/10.1002/jqs.685, 2002.

Page, S. E., Rieley, J. O., and Banks, C. J.: Global and regional importance of the tropical peatland carbon pool, Glob. Change Biol., 17, 798-818, https://doi.org/10.1111/j.13652486.2010.02279.x, 2011.

Panait, A., Diaconu, A., Galka, M., Grindean, R., Hutchinson, S., Hickler, T., Lamentowicz, M., Mulch, A., Tanţău, I., Werner, C., and Feurdean, A.: Hydrological conditions and carbon accumulation rates reconstructed from a mountain raised bog in the Carpathians: A multi-proxy approach, CATENA, 152, 5768, https://doi.org/10.1016/j.catena.2016.12.023, 2017.

Panait, A. M., Hutchinson, S. M., Diaconu, A. C., Tanţău, I., and Feurdean, A.: Disentangling dust and sand deposition using a peat record in CE Europe (northern Romania): A multiproxy approach, Palaeogeogr. Palaeocl., 532, 109257, https://doi.org/10.1016/j.palaeo.2019.109257, 2019.

Payne, R. J., Ring-Hrubesh, F., Rush, G., Sloan, T. J., Evans, C. D., and Mauquoy, D.: Peatland initiation and carbon accumulation in the Falkland Islands, Quaternary Sci. Rev., 212, 213-218, https://doi.org/10.1016/J.QUASCIREV.2019.03.022, 2019.

Perşoiu, I.: Reconstituirea evoluţiei geomorfologice a văii Someşul Mic în Holocen, Universitatea Al. I. Cuza Iaşi, Iaşi, 2010.

Perşoiu, I. and Perşoiu, A.: Flood events in Transylvania during the Medieval Warm Period and the Little Ice Age, Holocene, 29, 8596, https://doi.org/10.1177/0959683618804632, 2019.

Perşoiu, A., Onac, B. P., Wynn, J. G., Blaauw, M., Ionita, M., and Hansson, M.: Holocene winter climate variability in Central and Eastern Europe, Sci. Rep., 7, 1196, https://doi.org/10.1038/s41598-017-01397-w, 2017.

Perşoiu, A., Ionita, M., and Weiss, H.: Atmospheric blocking induced by the strengthened Siberian High led to drying in west Asia during the $4.2 \mathrm{kaBP}$ event - a hypothesis, Clim. Past, 15, 781-793, https://doi.org/10.5194/cp-15-781-2019, 2019.

Pop, E.: Mlaştinile de turbă din Republica Populară Română (Peat bogs from Romania), Editura Academiei Republicii Populare Române, Bucharest, 1960.

Popa, I. and Kern, Z. Z.: Long-term summer temperature reconstruction inferred from tree-ring records from the Eastern Carpathians, Clim. Dynam., 32, 1107-1117, https://doi.org/10.1007/s00382-008-0439-x, 2009. 
Pratte, S., Bao, K., Sapkota, A., Zhang, W., Shen, J., Le Roux, G., and De Vleeschouwer, F.: $14 \mathrm{kyr}$ of atmospheric mineral dust deposition in north-eastern China: A record of palaeoclimatic and palaeoenvironmental changes in the Chinese dust source regions, Holocene, 30, 492-506, https://doi.org/10.1177/0959683619892661, 2020.

Ratcliffe, J. L., Payne, R. J., Sloan, T. J., Smith, B., Waldron, S., Mauquoy, D., Newton, A., Anderson, A. R., Henderson, A., and Andersen, R.: Holocene carbon accumulation in the peatlands of northern Scotland, Mires Peat, 23, 1-30, https://doi.org/10.19189/MaP.2018.OMB.347, 2018.

Ratcliffe, J. L., Lowe, D. J., Schipper, L. A., Gehrels, M. J., French, A. D., and Campbell, D. I.: Rapid carbon accumulation in a peatland following Late Holocene tephra deposition, New Zealand, Quaternary Sci. Rev., 246, 106505, https://doi.org/10.1016/j.quascirev.2020.106505, 2020.

Reimer, P. J., Austin, W. E. N., Bard, E., Bayliss, A., Blackwell, P. G., Bronk Ramsey, C., Butzin, M., Cheng, H., Edwards, R. L., Friedrich, M., Grootes, P. M., Guilderson, T. P., Hajdas, I., Heaton, T. J., Hogg, A. G., Hughen, K. A., Kromer, B., Manning, S. W., Muscheler, R., Palmer, J. G., Pearson, C., Van Der Plicht, J., Reimer, R. W., Richards, D. A., Scott, E. M., Southon, J. R., Turney, C. S. M., Wacker, L., Adolphi, F., Büntgen, U., Capano, M., Fahrni, S. M., Fogtmann-Schulz, A., Friedrich, R., Köhler, P., Kudsk, S., Miyake, F., Olsen, J., Reinig, F., Sakamoto, M., Sookdeo, A., and Talamo, S.: The IntCal20 Northern Hemisphere Radiocarbon Age Calibration Curve (0-55 cal kBP), Radiocarbon, 62, 725-757, https://doi.org/10.1017/RDC.2020.41, 2020.

Roberts, N., Moreno, A., Valero-Garcés, B. L., Corella, J. P., Jones, M., Allcock, S., Woodbridge, J., Morellón, M., Luterbacher, J., Xoplaki, E., and Türkeş, M.: Palaeolimnological evidence for an east-west climate see-saw in the Mediterranean since $\mathrm{AD}$ 900, Global Planet. Change, 84-85, 23-34, https://doi.org/10.1016/j.gloplacha.2011.11.002, 2012.

Roulet, N. T., Lafleur, P. M., Richard, P. J. H., Moore, T. R., Humphreys, E. R., and Bubier, J.: Contemporary carbon balance and late Holocene carbon accumulation in a northern peatland, Glob. Change Biol., 13, 397-411, https://doi.org/10.1111/j.13652486.2006.01292.x, 2007.

Ruddiman, W. F. and Ellis, E. C.: Effect of per-capita land use changes on Holocene forest clearance and $\mathrm{CO}_{2}$ emissions, Quaternary Sci. Rev., 28, 3011-3015, https://doi.org/10.1016/j.quascirev.2009.05.022, 2009.

Ruddiman, W. F., Kutzbach, J. E., and Vavrus, S. J.: Can natural or anthropogenic explanations of late-holocene $\mathrm{CO}_{2}$ and $\mathrm{CH}_{4}$ increases be falsified?, edited by: Ruddiman, W. F., Crucifix, M. C., and Oldfield, F. A., Holocene, 21, 865-879, https://doi.org/10.1177/0959683610387172, 2011.

Sava, T. B., Simion, C. A., Gâza, O., Stanciu, I. M., Păceșilă, D. G., Sava, G. O., Wacker, L., tefan, B., Moșu, V.D., Ghiță, D. G., and Vasiliu, A.: Status report on the sample preparation laboratory for radiocarbon dating at the new Bucharest RoAMS center, Radiocarbon, 61, 649-658, 2019.

Schaefer, K., Lantuit, H., Romanovsky, V. E., Schuur, E. A. G., and Witt, R.: The impact of the permafrost carbon feedback on global climate, Environ. Res. Lett., 9, 085003, https://doi.org/10.1088/1748-9326/9/8/085003, 2014.

Schillereff, D., Chiverrell, R., Sjöström, J., Kylander, M., Boyle, J., Davies, J., Toberman, H., and Tipping, E.: Phosphorus sup- ply controls the long-term functioning of mid-latitude ombrotrophic peatlands, EarthArXiv Prepr., online, available at: https://eartharxiv.org/repository/view/2165/ (last access: $19 \mathrm{Au}-$ gust 2021), 2021.

Schnitchen, C., Charman, D. J., Magyari, E., Braun, M., Grigorszky, I., Tóthmérész, B., Molnár, M., and Szántó, Z.: Reconstructing hydrological variability from testate amoebae analysis in Carpathian peatlands, J. Paleolimnol., 36, 1-17, https://doi.org/10.1007/s10933-006-0001-y, 2006.

Schumacher, M., Schier, W., and Schütt, B.: Mid-Holocene vegetation development and herding-related interferences in the Carpathian region, Quatern. Int., 415, 253-267, https://doi.org/10.1016/j.quaint.2015.09.074, 2016.

Schuur, E. A. G., McGuire, A. D., Schädel, C., Grosse, G., Harden, J. W., Hayes, D. J., Hugelius, G., Koven, C. D., Kuhry, P., Lawrence, D. M., Natali, S. M., Olefeldt, D., Romanovsky, V. E., Schaefer, K., Turetsky, M. R., Treat, C. C., and Vonk, J. E.: Climate change and the permafrost carbon feedback, Nature, 520, 171-179, https://doi.org/10.1038/nature14338, 2015.

Tahvanainen, T.: Abrupt ombrotrophication of a boreal aapa mire triggered by hydrological disturbance in the catchment, J. Ecol., 99, 404-415, https://doi.org/10.1111/j.1365-2745.2010.01778.x, 2011.

Tóth, M., Magyari, E. K., Buczkó, K., Braun, M., Panagiotopoulos, K., and Heiri, O.: Chironomid-inferred Holocene temperature changes in the South Carpathians (Romania), Holocene, 25, 569-582, https://doi.org/10.1177/0959683614565953, 2015.

Tóth, M., Buczkó, K., Specziár, A., Heiri, O., Braun, M., Hubay, K., Czakó, D., and Magyari, E. K.: Limnological changes in South Carpathian glacier-formed lakes (Retezat Mountains, Romania) during the Late Glacial and the Holocene: A synthesis, Quatern. Int., 477, 138-152, https://doi.org/10.1016/j.quaint.2017.05.023, 2018.

Treat, C. C., Kleinen, T., Broothaerts, N., Dalton, A. S., Dommaine, R., Douglas, T. A., Drexler, J. Z., Finkelstein, S. A., Grosse, G., Hope, G., Hutchings, J., Jones, M. C., Kuhry, P., Lacourse, T., Lähteenoja, O., Loisel, J., Notebaert, B., Payne, R. J., Peteet, D. M., Sannel, A. B. K., Stelling, J. M., Strauss, J., Swindles, G. T., Talbot, J., Tarnocai, C., Verstraeten, G., Williams, C. J., Xia, Z., Yu, Z., Väliranta, M., Hättestrand, M., Alexanderson, H., and Brovkin, V.: Widespread global peatland establishment and persistence over the last 130,000 y, P. Natl. Acad. Sci. USA, 116, 4822-4827, https://doi.org/10.1073/pnas.1813305116, 2019.

Turetsky, M. R., Donahue, W. F., and Benscoter, B. W.: Experimental drying intensifies burning and carbon losses in a northern peatland, Nat. Commun., 2, 1-5, https://doi.org/10.1038/ncomms1523, 2011.

Turunen, J., Tomppo, E., Tolonen, K., and Reinikainen, A.: Estimating carbon accumulation rates of undrained mires in Finlandapplication to boreal and subarctic regions, The Holocene, 12, 69-80, 2002.

Varga, G., Kovács, J., and Újvári, G.: Analysis of Saharan dust intrusions into the Carpathian Basin (Central Europe) over the period of 1979-2011, Global Planet. Change, 100, 333-342, https://doi.org/10.1016/j.gloplacha.2012.11.007, 2013.

Varga, G., Cserháti, C., Kovács, J., and Szalai, Z.: Saharan dust deposition in the Carpathian Basin and its possible effects on interglacial soil formation, Aeolian Res., 22, 1-12, https://doi.org/10.1016/j.aeolia.2016.05.004, 2016. 
Vereș, D. .: A comparative study between loss on ignition and total carbon analysis on mineralogenic sediments, Studia UBB Geologia, 47, 171-182, 2002.

Wagner, B., Aufgebauer, A., Vogel, H., Zanchetta, G., Sulpizio, R., and Damaschke, M.: Late Pleistocene and Holocene contourite drift in Lake Prespa (Albania/F. Y. R. of Macedonia/Greece), Quatern. Int., 274, 112-121, https://doi.org/10.1016/j.quaint.2012.02.016, 2012.

Wang, M. and Moore, T. R.: Carbon, Nitrogen, Phosphorus, and Potassium Stoichiometry in an Ombrotrophic Peatland Reflects Plant Functional Type, Ecosystems, 17, 673-684, https://doi.org/10.1007/s10021-014-9752-x, 2014.

Warren, M., Hergoualc'h, K., Kauffman, J. B., Murdiyarso, D., and Kolka, R.: An appraisal of Indonesia's immense peat carbon stock using national peatland maps: Uncertainties and potential losses from conversion, Carbon Balance and Management, 12, 12, https://doi.org/10.1186/s13021-017-0080-2, 2017.
Webster, K. L., Bhatti, J. S., Thompson, D. K., Nelson, S. A., Shaw, C. H., Bona, K. A., Hayne, S. L., and Kurz, W. A.: Spatiallyintegrated estimates of net ecosystem exchange and methane fluxes from Canadian peatlands, Carbon Balance and Management, 13, 1-21, https://doi.org/10.1186/s13021-018-0105-5, 2018.

Worrall, F. and Clay, G. D.: The impact of sheep grazing on the carbon balance of a peatland, Sci. Total Environ., 438, 426-434, https://doi.org/10.1016/j.scitotenv.2012.08.084, 2012.

Young, D. M., Baird, A. J., Charman, D. J., Evans, C. D., Gallego-Sala, A. V., Gill, P. J., Hughes, P. D. M., Morris, P. J., and Swindles, G. T.: Misinterpreting carbon accumulation rates in records from near-surface peat, Sci. Rep., 9, 1-8, https://doi.org/10.1038/s41598-019-53879-8, 2019.

Yu, Z., Loisel, J., Brosseau, D. P., Beilman, D. W., and Hunt, S. J.: Global peatland dynamics since the Last Glacial Maximum, Geophys. Res. Lett., 37, L13402, https://doi.org/10.1029/2010GL043584, 2010. 